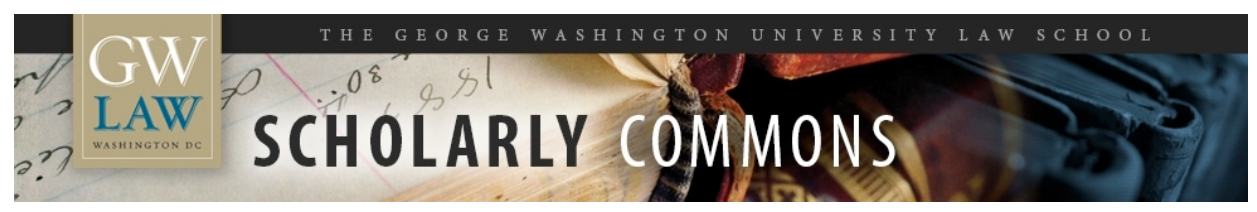

\title{
The Case for Registering Patents and the Law and Economics of Present Patent-Obtaining Rules
}

\author{
F. Scott Kieff \\ George Washington University Law School, skieff@law.gwu.edu
}

Follow this and additional works at: https://scholarship.law.gwu.edu/faculty_publications

Part of the Law Commons

\section{Recommended Citation}

Kieff, F. Scott, "The Case for Registering Patents and the Law and Economics of Present Patent-Obtaining Rules" (2004). GW Law Faculty Publications \& Other Works. 568.

https://scholarship.law.gwu.edu/faculty_publications/568

This Article is brought to you for free and open access by the Faculty Scholarship at Scholarly Commons. It has been accepted for inclusion in GW Law Faculty Publications \& Other Works by an authorized administrator of Scholarly Commons. For more information, please contact spagel@law.gwu.edu. 
JEL ClassifiCATIONS: K11, K21, K22

K23, K39, K41, L40, O31, O34, P14

\title{
The CASE For Registering PATENTS AND THE \\ LAW AND ECONOMICS OF PRESENT PATENT-OBTAINING RULES
}

\author{
F. Scott Kieff*
}

(C) 2003. F. Scott Kieff. All Rights Reserved.

\begin{abstract}
(Note: this is a substantially revised version of Harvard Olin Working Paper \# 415 of May 2003, SSRN Abstract ID \# 392202, and includes more detailed discussion of issues including the DOE, willfulness and the Knorr decision, and the FTC Report on patents and antitrust).

Critics of the patent system suggest the rules for determining patentability should be stricter, subjecting patents to more scrutiny during Patent Office examination. This Article offers a counterintuitive model system under which patent applications are registered, not examined, to elucidate a new normative view that sees present positive law rules for obtaining patents as primarily operating to minimize social cost, and that accounts for otherwise puzzling aspects of the patent system. This "registration" theory for patentobtaining rules is a companion to the "commercialization" theory for patent-enforcing rules by the same author. This Article shows how these theories together offer a more coherent view of the patent system than the "reward," "prospect," and "rent dissipation" theories. This Article further identifies those patentability rules that are essential and those that should be reformed, while revealing inherent registration aspects of our present system and reasons for eschewing reforms presented elsewhere.
\end{abstract}

* The author is 2003-2004 W. Glenn Campbell \& Rita Ricardo-Campbell National Fellow and Robert Eckles Swain National Fellow at Stanford University's Hoover Institution and Associate Professor and 2003-2004 Israel Treiman Faculty Research Fellow at Washington University School of Law. At the time this essay was first presented, he was 2001-2002 and 20022003 John M. Olin Senior Research Fellow in Law, Economics, and Business at Harvard Law School. The author gratefully acknowledges the financial support of the John M. Olin Foundation and the Washington University School of Law. He also gratefully acknowledges contributions from participants in the Fall 2003 Hoover Economics Lunch Seminar, American Law and Economics Association 2003 Annual Meeting, the Harvard Law School Visiting Scholars and Visiting Researchers 2002-2003 Colloquium, the Federal Trade Commission and Department of Justice Antitrust Division 2002 joint hearings on Competition and Intellectual Property, the 2001 Workshop Series of the John M. Olin Program in Law and Economics at the University of Chicago Law School, and the 2002 and 2001 National Lawyers Conventions of the Federalist Society for Law and Public Policy Studies, as well as the more detailed comments provided by Michael Abramowicz, John R. Allison, Kenneth Arrow, John Barton, Bernard Black, Bruce Bueno de Mesquita, Chris Bracey, Lisa English, Richard Epstein, Paul Goldstein, Wendy Gordon, Joseph Grundfest, Robert Hall, Kenneth Judd, Jay Kesan, Edward Lazear, Mark Lemley, Doug Lichtman, Clarissa Long, Jerry Marr, Rob Merges, Michael Meurer, Arie Michelsohn, Pauline Newman, Troy Paredes, Tom Pasternak, Richard Posner, Marco Quina, Randall Rader, Arti Rai, Michael Schwartz, Steve Shavell, Henry Smith, Jay Thomas, Polk Wagner, and John Witherspoon. Please send correspondence to fskieff.91@alum.mit.edu (permanent address).

(printed 2/19/2004) 


\title{
THE CASE FOR REGISTERING PATENTS AND THE \\ LAW AND ECONOMICS OF PRESENT PATENT-OBTAINING RuleS
}

\author{
F. Scott Kieff
}

(C) 2003. F. Scott Kieff. All Rights Reserved.

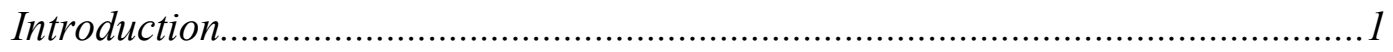

I. Context Within the Patent Law \& Economics Literature ...................................6

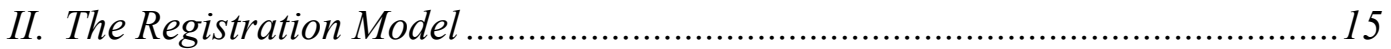

III. The Law \& Economics of Patent-Obtaining Rules ........................................20

A. The Prior Art Rules Inexpensively Protect Investment ..............................21

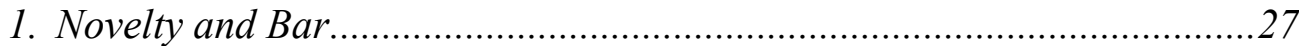

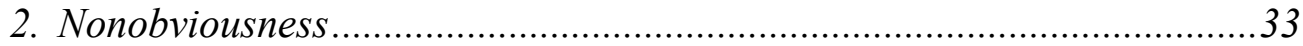

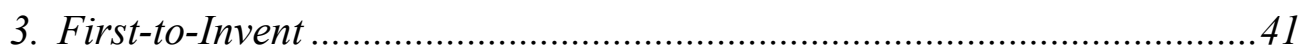

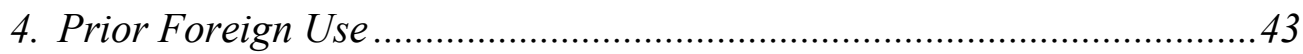

B. The Disclosure Rules Help Coordinate ……………….............................44

C. Summary: The Name of the Game is the Claim...........................................46

IV. Lessons from the Model for the Present Patent System .................................50

A. Reforms for Subject Matter and Utility ....................................................51

B. Reforms for the Doctrine of Equivalents ...................................................54

C. Reforms for Deference to the Patent Office...............................................59

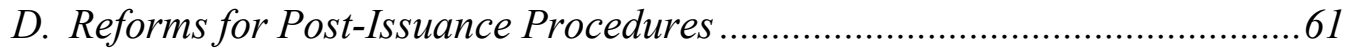

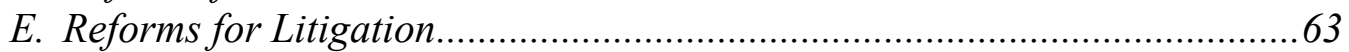

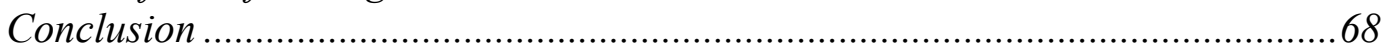

\section{INTRODUCTION}

Allowing an Internet shopper, who is a regular customer of a web site, to complete her selected purchase without having to click a confirmatory button indicating she really meant to buy it may hardly seem like something a wellfunctioning patent office should have found appropriate for patent protection in 1997. ${ }^{1}$ Yet, a federal court issued a preliminary injunction to enforce such a patent against Barnesandnoble.com during the 1999 Christmas season, requiring customers to make two or more clicks to complete purchases on that site- a

\footnotetext{
${ }^{1}$ But see U.S. Patent No. 5,960,411 (issued Sept. 28, 1999) (entitled "Method and System for Placing a Purchase Order via a Communications Network," listing Jeff Bezos and others as inventors and assigned to Amazon.com, Inc., which covers what is colloquially called "one-click shopping," the application for which was filed on September 12, 1997).
} 
potential annoyance to them and a cause of lost revenue for the company. ${ }^{2}$ Although the preliminary injunction was eventually vacated on appeal based on the questionable validity of the patent in view of the prior art, ${ }^{3}$ the defendant's litigation costs to obtain this result could not have been minor. ${ }^{4}$

The threat of cases like this has prompted the Federal Trade Commission and the Justice Department's Antitrust Division to ask in their announcement of joint hearings on such issues:

To what extent do questions about the scope and types of patents (e.g., business methods patents), and the procedures and criteria under which they are issued, raise competition issues? To what extent do substantive and procedural rules, both at agency and judicial levels, have implications for initial and sequential innovation, competition, and appropriability ${ }^{5}$

The hearings that followed this announcement spanned most of 2001, during which many critics of the patent system argued that the system may be in steep decline due to an increase in the number of patents issued by the U.S. Patent and Trademark Office (the "Patent Office") that these critics suggest do not meet the

2 Amazon.com, Inc. v. Barnesandnoble.com, Inc., 73 F. Supp. 2d 1228, 1249 (W.D. Wash. 1999) (granting motion for preliminary injunction on December 1), vacated and remanded by 239 F.3d 1343 (Fed. Cir. 2001).

${ }^{3}$ Amazon.com, Inc. v. Barnesandnoble.com, Inc., 239 F.3d 1342, 1366 (2001) (vacating and remanding because of "substantial questions as to the validity of the ' 411 patent").

4 The published order of the trial court lists thirteen different attorneys on the side of the defendant. Amazon.com, 73 F. Supp. 2d at 1230. The case was filed on October 21, 1999, and the preliminary injunction was entered roughly seven weeks later, after expedited discovery including depositions and five days of oral arguments. Given the emergent need to handle so many tasks in such a case, it fairly may be assumed that the listed attorneys were billing most, say two-thirds, of their time on the case while working most of the time, say twelve-hour days six days a week. At a blended rate of $\$ 250$ per hour, this suggests the total legal fees through the entry of the preliminary injunction were over one million dollars $(\$ 1,092,000)$. The fees through the appeal are likely to have been at least another one million dollars, based on similar calculations. See Am. Intellectual Prop. Law Ass'n, Report of Economics Survey 2001, at 88-89 tbl.22 (2001) (reporting the median total cost of litigation including discovery, motion practice, trial, and appeal to be $\$ 1.5$ million or \$2.9 million, depending upon whether the amount at stake in the lawsuit was either from $\$ 1-\$ 25$ million or greater than $\$ 25$ million).

${ }^{5}$ Notice of Public Hearings Competition and Intellectual Property Law and Policy in the Knowledge-Based Economy, 66 Fed. Reg. 58,146, 58,147 (Nov. 20, 2001) (announcing joint hearings and explaining the reasons for them); see also Press Release, Federal Trade Commission, Muris Announces Plans for Intellectual Property Hearings (Nov. 15, 2001) (collecting sources, including links to Federal Register Notice and to speech by Chairman Timothy Muris, and questioning these and other aspects of the patent system), http://www.ftc.gov/opa/2001/11/iprelease.htm (last visited Nov. 13, 2003). 
proper patentability standards and, as a result, are too broad or too narrow, unduly tax and retard negotiations, or frustrate competition. ${ }^{6}$

Although a ratcheting up of the screening done in the first instance by the Patent Office, to achieve a more "hard-look" examination, is an intuitive and often-urged response, this Article makes the counterintuitive suggestion that instead, the Patent Office should do a "soft-look" examination, if any examination

${ }^{6}$ For a schedule of the hearings including participants and topics, see http://www. ftc.gov/opp/intellect/detailsandparticipants.htm (last visited Nov. 13, 2003). For a collection of academic and popular literature making these criticisms, see Mark A. Lemley, Rational Ignorance at the Patent Office, 95 Nw. U. L. Rev. 1495, 1495 n.1 (2001).

Although many see only broad scope as a potential problem because the patent right to exclude may be seen as extending too far, others see a couple of problems associated with narrowness. First, the work by Rebecca Eisenberg and others points out how too many patents of too narrow scope can be seen to unduly tax and retard transactions. See Arti Kaur Rai, Regulating Scientific Research: Intellectual Property Rights and the Norms of Science, 94 Nw. U. L. Rev. 77, 126-29 (1999) (suggesting that patents on multiple gene fragments, such as expressed sequence tags, could block the use of a larger DNA sequence of which they are a part, and citing Michael A. Heller \& Rebecca S. Eisenberg, Can Patents Deter Innovation? The Anticommons in Biomedical Research, 280 Science 698, 699 (1998) (arguing that patents can deter innovation in the field of basic biological research)). This argument and its implications are explored in depth in the other important works by Eisenberg. See generally Rebecca S. Eisenberg, Patents and the Progress of Science: Exclusive Rights and Experimental Use, 56 U. Chi. L. Rev. 1017 (1989) [hereinafter Eisenberg, Experimental Use] (exploring an experimental use exemption from patent infringement as a device for alleviating potential negative impact of patent rights on scientific norms in the field of basic biological research); Rebecca S. Eisenberg, Property Rights and the Norms of Science in Biotechnology Research, 97 Yale. L.J. 177 (1987) [hereinafter Eisenberg, Norms of Science] (exploring potential negative impact of patent rights on scientific norms in the field of basic biological research); Rebecca S. Eisenberg, Public Research and Private Development: Patents and Technology Transfer in Government-Sponsored Research, 82 Va. L. Rev. 1663 (1996) [hereinafter Eisenberg, Public Research] (offering preliminary observations about the empirical record of the use of patents in the field of basic biological research and recommending a retreat from present government policies of promoting patents in that field). But see F. Scott Kieff, Facilitating Scientific Research: Intellectual Property Rights and the Norms of Science-A Response to Rai and Eisenberg, 95 Nw. U. L. Rev. 691, 699-700 (2001) (showing why a patent claim directed to a gene fragment like an expressed sequence tag ("EST") cannot be construed to cover a larger DNA sequence, such as a substantial portion of an entire gene); John P. Walsh et al., Research Tool Patenting and Licensing and Biomedical Innovation 1 (2002) (working paper, available online at http://www.heinz.cmu.edu/wpapers/retrievePDF? id=2003-2) (report of empirical research finding little in the way of anticommons problems with biotech research tools). Second, the work by Robin Jacob and others point out how claims of narrow scope may be enforced in ways that avoid significant antitrust scrutiny. Robin Jacob, Side Bar: Objectionable Narrowness of Claim, in Donald S. Chisum, Craig A. Nard, Herbert F. Schwartz, Pauline Newman, \& F. Scott Kieff, Principles of Patent Law 1097-99 (2d ed. 2001) (providing examples and collecting sources of early arguments supporting pro-competitive aspects of narrow claims). 
at all. ${ }^{7}$ This Article focuses on a comparative analysis because the question any evaluator must always ask is not whether any one system has negative aspects, but rather how it compares to alternatives. ${ }^{8}$

To best understand the intuition behind soft-look systems generally, this Article offers as a model a hypothetical alternative system under which patent applications are registered, not examined. ${ }^{9}$ Study of this model reveals both how the social costs associated with hard-look examination systems are especially large and how the costs associated with soft-look systems - such as the present system and the model registration system - are especially small. ${ }^{10}$

In focusing on social cost, this Article offers a new normative account of the positive law rules for obtaining patents. ${ }^{11}$ The registration theory offered in this Article shows how the essential patentability rules mitigate significant social costs and how existing normative views of the patent system fail to account for these social costs. ${ }^{12}$ Far from defending the present patent system, this Article offers a number of significant modifications expected to mitigate social costs further by embracing, somewhat counterintuitively, the admittedly expensive tools of commercial litigation. ${ }^{13}$

In the final analysis, the prescriptive conclusions this Article reaches are somewhat modest. ${ }^{14}$ Although the conclusions of this Article are limited in part because they are likely to turn on empirical determinations and balancing that cannot be done responsibly without further data, this Article does provide a new

7 The "hard-look" and "soft-look" terminology refers to the level of scrutiny given a patent upon filing. Although at least some patents should get a hard look at some point, this Article shows how the social costs associated with providing a hard look through civil litigation are expected to be less, especially when accompanied by the other important features of the patent system discussed infra in Part IV.

${ }^{8}$ See Harold Demsetz, Information and Efficiency: Another Viewpoint, 12 J.L. \& Econ. 1, 1 (1969) (critiquing so-called nirvana approaches in favor of comparative institutional approaches).

${ }^{9}$ See infra Part II.

${ }^{10}$ See infra Parts III-IV.

${ }^{11}$ The Article thereby builds on earlier work by the present author that offers a normative account of the rules for enforcing patents. See generally F. Scott Kieff, Property Rights and Property Rules for Commercializing Inventions, 85 Minn. L. Rev. 697 (2001).

12 See infra Parts I-IV.

${ }^{13}$ See infra Part IV.

${ }^{14}$ See infra Part IV. 
and practicable framework for making such evaluations. ${ }^{15}$ In addition, although we already may be operating under a de facto soft-look system, at least in many respects, this Article offers several reforms designed to bring the present system more in line with soft-look systems like the proposed registration model. ${ }^{16}$ Furthermore, the conclusions drawn here may be influenced by our broader views on the comparative strengths of different decision-making regimes, such as between those that are centralized and those that are individualized and dispersed, and between those based on rules and those based on standards. ${ }^{17}$ Regardless of the prescriptive value any of this Article's conclusions may have for positive patent law directly, this Article's unique elucidation of a normative account of the patent-obtaining rules as operating to minimize certain social costs will help commentators and policymakers evaluate other proposed reforms in the future. ${ }^{18}$

This Article proceeds in four parts as follows: Part I reviews the existing normative theories of the patent system and shows how they fail to offer practicable approaches for a positive law regime and fail to minimize social costs. ${ }^{19}$ Part II explores the case for an alternative hypothetical model of a registration system and shows how social costs can be minimized by use of such a

${ }^{15}$ As discussed infra in Parts I-IV, the registration theory's ease of implementation is one of the theory's important comparative benefits over other theories of the patent system, such as the "prospect" and "rent dissipation" theories.

${ }^{16}$ See infra Part IV.

${ }^{17}$ For a discussion of the broader debate between legal systems based on rules and those based on standards, see generally Mark Kelman, A Guide To Critical Legal Studies 15-63 (1987) (describing basic framework of the debate and collecting sources); Louis Kaplow, Rules Versus Standards: An Economic Analysis, 42 Duke L.J. 557 (1992) (exploring the costs implicated by the choice between rules and standards and showing: rules typically are more costly than standards to create; standards typically are more costly for individuals to interpret, both by individuals deciding how to act under them and by government decisionmakers deciding how to apply them; and individuals are more likely to act in accordance with the goals of rules as long as the individuals can determine how they will be applied); Russell B. Korobkin, Behavioral Analysis and Legal Form: Rules vs. Standards Revisited, 79 Or. L. Rev. 23 (2000) (reviewing more recent literature and collecting sources). Compare Robert Cooter \& Thomas Ulen, Law and Economics 100 (1988) (arguing that private bargaining over the allocation of the legal entitlement may be more efficient if the entitlement is clearly defined and assigned ex ante according to a rule, rather than made ex post by a judge applying a standard), with Jason Scott Johnston, Bargaining Under Rules Versus Standards, 11 J.L. Econ. \& Org. 256, 256-59 (1995) (showing how parties may negotiate with each other under both types of regimes and arguing that in certain two-party cases, bargaining may be more efficient under a standard than under a rule).

${ }^{18}$ As discussed infra Parts I-IV, the registration theory's explanatory power for the present patent system is another of the theory's important comparative benefits over other theories of the patent system, such as the "reward," "prospect," and "rent dissipation" theories.

${ }^{19}$ See infra notes 23-65 and accompanying text. 
system. ${ }^{20}$ Part III reviews the law and economics of the core patent-obtaining rules and shows how the registration theory is superior to other normative theories, both in ability to be implemented and in ability to account for the patentobtaining rules in the present system. ${ }^{21}$ Part IV compares the pure registration model to the present system and then offers some proposed reforms to the present system. $^{22}$

\section{Context Within the Patent LaW \& ECONOMics Literature}

Prevailing normative views of the patent system fail to account for significant social costs that are mitigated by many of the present patentability rules. ${ }^{23}$ Although the prevailing views do provide important lessons about how the patent system can mitigate certain social costs, they fail to show, in any practical way, how to mitigate others, or how to mitigate social cost overall. More specifically, they fail to address important issues such as how to evaluate an invention, either to determine its entitlement to some patent or other reward, or to determine its relative entitlement when compared with other inventions. ${ }^{24}$ These issues turn out not to be small administrative matters. ${ }^{25}$ The normative view offered in this Article shows how the present patent system has evolved essential tools for making these determinations in ways that mitigate social cost. ${ }^{26}$

The patent system in this country has generally been seen as offering inventors an incentive to do something they might not otherwise do-for example, invent, disclose, commercialize, or design around. ${ }^{27}$ These incentives are generated by the grant in each patent of the right to exclude others from doing whatever is covered by the patent's claims. ${ }^{28}$ Recognizing that discrete incentives

${ }^{20}$ See infra notes 66-84 and accompanying text.

${ }^{21}$ See infra notes 85-222 and accompanying text.

${ }^{22}$ See infra notes 223-291 and accompanying text.

${ }^{23}$ See infra Part III, elucidating the law and economics of the core patent-obtaining rules and showing how the registration theory dominates other normative theories both in ability to be implemented and in ability to account for the patent-obtaining rules in the present system.

${ }^{24}$ See infra notes 46-49 and accompanying text.

${ }^{25}$ See infra Part III, showing how these issues are addressed by the present patentobtaining rules.

${ }^{26}$ See infra Part III.

${ }^{27}$ For a review of the literature and a collection of sources, see Chisum et al., supra note 6, at 58-90 (reviewing various incentive theories for the patent system) and Eisenberg, Experimental Use, supra note 6, at 1024-46 (same).

${ }^{28}$ Patents give only a right to exclude use of whatever product or process is covered by the patent's claim or claims. Thus, for example, patents do not interfere with other governmental 
like these, focused on inventors, could be provided directly without the outputrestricting effects of the patent right to exclude, commentators have for over a century explored alternative ways to provide these incentives using tools such as cash rewards and tax credits. ${ }^{29}$

In his 1977 piece on the so-called prospect theory of the patent system, which builds upon work by Yoram Barzel and others, Edmund Kitch showed how granting formal property rights, as opposed to cash rewards, is important for avoiding the social costs associated with racing towards a common prize. ${ }^{30}$ Called rent dissipation by Mark Grady and Jay Alexander in $1992,{ }^{31}$ the racing problem can be demonstrated by the example of an uncoordinated group of individuals who are each seeking a prize of known value. Each such individual might rationally elect to spend up to just less than the value of the prize to get it, meaning that as a group they are spending more in aggregate than the value of the prize. $^{32}$

efforts to restrict use, such as to mitigate environmental impact. See F. Scott Kieff, Patents for Environmentalists, 9 Wash. U. J.L. \& Pol'y 307, 308 (2002) (invited symposium piece for National Association of Environmental Law Societies annual meeting entitled "Sustainable Agriculture: Food for the Future," held March 15-17, 2002, at Washington University School of Law) (citing 35 U.S.C. § 154(a) (1994) ("Every patent shall contain ... a grant to the patentee ... of the right to exclude others ....")).

${ }^{29}$ Generally, prizes or rewards are thought to offer two main benefits over patents: (1) they do not confer power over price; and (2) they can be made later in time, after the demand curves are knowable, so a more precise calculation of the social benefit of the invention can be determined and then used when setting the reward amount. For a detailed review of the history and modern iterations of prize proposals, including a new improvement thereon, see generally Michael Abramowicz, Perfecting Patent Prizes, 56 Vand. L. Rev. 115 (2003) (collecting sources and arguing for the establishment of an agency to distribute a fund for rewarding corporate efforts to reduce the monopoly effects of patent rights). Determining how to administer rewards in the real world is a central problem the commercialization theory identifies in reward proposals, as well as any reward-based theory of patents. See Kieff, supra note 11, at 712-17 (discussing this problem in the context of the screening advantages of patents over rewards). Reward approaches and theories usually assume a one-to-one relationship between inventions and markets that can drastically deviate from reality - consider that the typical car or computer sold in a single market comprises a huge bundle of patent and other intellectual property rights. In addition, reward approaches do not elucidate how to determine what should be rewarded and how to allocate rewards among claimants.

${ }^{30}$ Edmund W. Kitch, The Nature and Function of the Patent System, 20 J.L. \& Econ. 265, 265-67 (1977) (citing Yoram Barzel, Optimal Timing of Innovations, 50 Rev. Econ. \& Stat. $348(1968))$.

${ }^{31}$ Mark F. Grady \& Jay I. Alexander, Patent Law and Rent Dissipation, 78 Va. L. Rev. 305, 305-10 (1992).

${ }^{32}$ Consider a case in which the value of the prize is $X$ and the group of individuals is $Y$ in number. Each individual might rationally elect to spend up to just less than $X$ to obtain the prize, 
Although rent dissipation can be a problem in theory, recent work by Michael Abramowicz adroitly points out a number of factors that may mitigate rent dissipation effects in practice. ${ }^{33}$ These factors include risk aversion; opportunity costs; diversity among those racing; the time it takes to get the reward; and externalized costs or benefits those racing impose on others, such as the income to those who sell goods and services needed by those racing or the costs to those who are bothered by the activities associated with racing. ${ }^{34}$

In addition, rent dissipation presumes there is a single prize, or at least a discrete number of prizes. ${ }^{35}$ But those attempting to solve a problem may not

say some amount equal to $X$ minus a small discount, say $\delta$, or $(X-\delta)$. Yet, if all individuals spend that amount, then the community has spent the amount equal to $[(X-\delta) \times Y]$ to obtain something worth only $X$. The following mathematical representation will be true as long as $X$ and $Y$ are numbers greater than one and $\mathrm{d}$ is a number less than one:

$$
[(X-\delta) \times Y]>Y
$$

This means that the amount society spent to obtain the prize is greater than the amount society got by obtaining the prize, which would be a waste of resources. To be sure, whether each individual would rationally elect to spend up to just less than $X$ depends on a number of factors. See, e.g., Dennis C. Mueller, Public Choice II 232 (1989); Terry L. Anderson \& Peter J. Hill, Privatizing the Commmons: An Improvement?, 50 S. Econ. J. 438, 441, 447 (1983). For a somewhat similar critique of the rent dissipation theory, see A. Samuel Oddi, Un-Unified Economic Theories of Patents-The Not-Quite-Holy Grail, 71 Notre Dame L. Rev. 267, 284-85 (1996).

${ }^{33}$ Michael Abramowicz, Copyright Redundancy 10-18 (George Mason Sch. of Law, Law \& Econ., Working Paper Series 03-03, 2003), available at http://ssrn.com/abstract_id $=374580$ (collecting sources and showing how each of these factors may operate to mitigate rent dissipation effects).

${ }^{34} I d$. at 11-12. A more palpable, albeit mythological, example of these positive externalities of racing might include the joy children experience when they drink the Tang ${ }^{\circledR}$ and use the Velcro® that many think were brought to society through the NASA-sponsored space race; the corresponding negative externalities might include the cavities some children get from increased exposure to this sugared drink and their difficulty tying knots after growing up with shoes kept on by hook-and-loop fasteners instead of laces. See, e.g., A. Samuel Oddi, An Uneasier Case for Copyright Than for Patent Protection of Computer Programs, 72 Neb. L. Rev. 351, 378 n.95 (1993):

\begin{abstract}
The creation of "spin off" inventions has often been urged as one of the benefits of governmentfunded research. See George J. Howick, The NASA Technology Utilization Program, in Utilizing R \& D By-Products 69, 78-82 (Jerome W. Blood ed., 1967) (describing NASA program and examples of spin-off inventions, including inorganic paint, walking wheel chair, maintenance-free lubricated bearings, and sight-controlled switches). Some other examples of commercial products arising out of the space program include, smoke detectors, graphite, an artificial pancreas, heated ski goggles and hang gliders, but not velcro, teflon or tang.
\end{abstract}

${ }^{35}$ Although it is often useful when modeling a problem to reduce it to a manageable form to construct the model, the single-solution element of the rent-seeking models cannot be extrapolated to provide meaningful guidance for policymakers without at least consideration of 
arrive at the same solution; they may get to different solutions and there may be even more solutions available. ${ }^{36}$ Although multiple solutions to a given problem may be wasteful when the good is not really needed, which is an interesting possibility explored at some length by Abramowicz, ${ }^{37}$ when the utility of the good is substantial, the benefits of multiple solutions may dominate. ${ }^{38}$ That is, although more may not always be better, it also may not always be worse. Consider the multiple, independently patentable and non-infringing solutions to the problem of pain and inflammation: aspirin, acetaminophen $\left(\right.$ Tylenol $^{\circledR}$ ), ibuprofen (Advil ${ }^{\circledR}$, Motrin $^{\circledR}$ ), selective COX-2 inhibitors (Vioxx ${ }^{\circledR}$ and Celebrex ${ }^{\circledR}$ ), and various steroids. ${ }^{39}$ Some patients can only take some of these drugs, and some patients can take all, but not at all times. In the real world we cannot know ex ante whether more solutions are going to be redundant, or whether they will both

whether in the real world the set of possible solutions to a given problem (prizes) is limited, and whether we are nearing such a limit.

${ }^{36}$ See infra note 39 and accompanying text.

37 Abramowicz, supra note 33, at 2-9. Interestingly, the fair use defense and the utility exception to copyrightable subject matter may combine to leave uses that are needed effectively beyond the enforceable reach of any valid copyright rights.

38 An increase in the number of available solutions will increase the chance of each person gaining access to any one solution. This is one reason why the patent system does not require the claimed invention to be "better" than the prior art, only new and nonobvious. As thenjudge Warren Burger wrote, quoting Judge Giles Rich:

\footnotetext{
Progress is most effectively promoted by protecting those who enrich the art as well as those who improve it. Even though their inventions are not as good as what really exists, such inventors are not being rewarded for standing still or for retrogressing, but for having invented something. The system is not concerned with the individual inventor's progress but only with what is happening to technology.
}

Comm'r of Patents v. Deutsche Gold-und-Silber-Scheideanstalt, 397 F.2d 656, 667 (D.C. Cir. 1968) (Burger, J.) (quoting Giles S. Rich, Principles of Patentability, 28 Geo. Wash. L. Rev. 393, 393, 402 (1960), reprinted in Nonobviousness - The Ultimate Condition of Patentability 2:1, 2:9 (John F. Witherspoon ed., 1980) (admonishing that we must avoid "the unsound notion that to be patentable an invention must be better than the prior art.").

39 It is not always the case that an independently patentable invention will avoid infringement of earlier patents. Patentability of the second invention turns on a very different set of questions than its possible infringement of the first patent. The patentability analysis of the second invention will turn largely on the scope of information in the art at the time that invention is sought to be patented, which includes the disclosure in the first patent. For more on the rules of patentability over the prior art, see Chisum et al., supra note 6, at 323-706 (treatise and casebook teaching and collecting sources). The possible analysis of infringement of the first patent by the second invention will turn on the claims of the first patent. For more on the rules of patent infringement, see $i d$. at 829-1041. 
increase consumer choice and provide access to more consumers who could not consume the earlier solutions. ${ }^{40}$

An additional problem with the prospect and rent dissipation theories is that they present themselves with the very problem they attempt to solve. As Donald McFetridge and Douglas Smith pointed out soon after Kitch, the more effective the patent is in coordinating activities of those in the industry after the patent has issued, ${ }^{41}$ the greater will be the problems of racing towards the patent application before filing. ${ }^{42}$ Kitch's response was to argue that the coordination costs are likely to be low in such early stages because there are likely to be only a small number of players then. ${ }^{43}$ But this response does not fully answer the problem. As Abramowicz correctly points out, the transaction costs may be high in such a community because the members may have significant cognitive biases. ${ }^{44}$ The transaction costs to coordinating may also be high if the racers do not know about each other. $^{45}$

But the central limitation of the rent dissipation and prospect theories is that they do not offer a way to use the social cost lessons of prospecting to design legal rules for obtaining patents that can operate ex ante to mitigate the social costs of prospecting. Instead, Kitch argues that the prospect theory explains why the commercial success associated with a patented invention should be an important factor in determining whether it is patentable. ${ }^{46}$

${ }^{40}$ In areas where we can make good judgments ex ante about which avenues of research are most likely to be productive, it may be possible to fund the work prospectively. The government grant-making processes such as those at NIH and NSF basically operate this way by empanelling experts in the field to review grant applications.

${ }^{41}$ Kitch, supra note 30 , at 276.

42 Donald G. McFetridge \& Douglas A. Smith, Patents, Prospects, and Economic Surplus: A Comment, 23 J.L. \& Econ. 197, 202-03 (1980).

43 Edmund W. Kitch, Patents, Prospects, and Economic Surplus: A Reply, 23 J.L. \& Econ. 205, 205-06 (1980).

44 Abramowicz, supra note 29, at $184 \mathrm{n} .251$ (collecting sources on cognitive biases of overconfidence and overoptimism).

45 They may not know each other because the field may be so new that the community of people working in it is not defined. Or, the potential members of the community may generally be known, but without the freedom to divulge their work to each other that is given by a patent, they may not know enough about each other to coordinate. This latter type of coordination problem is known generally as the Arrow Information Paradox. See Kenneth J. Arrow, Economic Welfare and the Allocation of Resources for Invention, in The Rate and Direction of Inventive Activity 609, 61619 (Nat'l Bureau of Econ. Research ed., 1962).

${ }^{46}$ Kitch, supra note 30, at 282-83 (discussing commercial success). Later in the same work, Kitch may be advocating that the test for patentability over the prior art should merely be novelty, without nonobviousness. See id. at 284 ("Thus substantial novelty is an economically 
Similarly, the rent dissipation theory urges a finely tuned patent system that will grant and enforce patents only when the balance of these pre-patent and post-patent racing costs tips just the right way. ${ }^{47}$ But the rent dissipation theory does not provide a framework for making such determinations ex ante, at the time a private party would decide whether to file a patent application or at the time the Patent Office would examine it. Instead, it only identifies a select few reported judicial decisions that, according to the summary accounts of Grady and Alexander, turn out to be ex post examples of results that may have avoided rent dissipation. $^{48}$

In the final analysis, at least to date, the prospect and rent dissipation theories provide important insights about how the patent system can both increase and decrease rent dissipation-type social costs. But the theories do not offer a tool for comparing these costs against other social costs, assessing net social costs, or doing all of this in a way that would work for making patentability determinations in a timely fashion. ${ }^{49}$

The importance of being able to make determinations about patentability and patent scope around the time of the application has been emphasized recently in a number of areas of the literature. R. Polk Wagner, in his work on the patent infringement doctrine called the "doctrine of equivalents," elucidates the importance of information-forcing penalty default rules as inducement to potential patentees to produce socially valuable information early in the life of the patent. ${ }^{50}$

rational test of patentability."). Such an argument would accord with the social cost saving benefits of the registration theory outlined here. See infra Part III.A.

${ }^{47}$ See Grady \& Alexander, supra note 31, at 322-47 (offering a complicated method for making patentability determinations using a host of factors, many of which are determined long after a patent application is filed, such as the importance of the patent in controlling downstream rent-dissipating effects).

${ }^{48} I d$. at 343-47 (discussing only a few cases in summary). Furthermore, one of the few cases Grady and Alexander rely upon as illustrative of the rent dissipation theory, General Mills v. Pillsbury Co., 378 F.2d 666 (8th Cir. 1967), does not accord with any of the prevailing trends in the case law over time. An electronic search using the Westlaw ${ }^{\circledR}$ KeyCite ${ }^{\circledR}$ service did not reveal a single case after 1974 that cited Pillsbury on this issue and further revealed that, if anything, the case is miscited by a commentator as announcing a per se rule against patents in the field of culinary arts. See Malla Pollack, Note, Intellectual Property Protection for the Creative Chef, or How to Copyright a Cake: A Modest Proposal, 12 Cardozo L. Rev. 1477, 1482 n.30 (1991) ("Food items are patentable, but the culinary creativity of chefs is not the type of creativity which meets the standards for patentability.").

${ }^{49}$ See supra notes 46-48 and accompanying text.

${ }^{50}$ R. Polk Wagner, Reconsidering Estoppel: Patent Administration and the Failure of Festo, 151 U. Pa. L. Rev. 159, 161-67 (2002) (arguing for a shift in focus from the allocation of liability during infringement (ex post) towards rules that generate incentives both during and before inventors apply for patents (ex ante) so as to better understand information-forcing default 
In addition, Clarissa Long, in her work on the often overlooked signaling function of patents, shows how in certain circumstances the information-signaling function of patents may be even more valuable to the rights holder than the substantive rights conferred by patent law. ${ }^{51}$

Similarly, my own earlier work on the commercialization theory of patents shows how the patent right to exclude operates, as designed, at the time after inventions are made to help bring such nascent inventions to market through the process called commercialization. ${ }^{52}$ According to this view, patents allow patentees, and the many others with whom they must negotiate, to achieve commercialization by allowing them to internalize the full benefits of the subject matter claimed, in keeping with the work by Harold Demsetz on the emergence of property rights generally. ${ }^{53}$ Also according to this view,

penalty rules like the limitation on the doctrine of equivalents known as the "doctrine of prosecution history estoppel," which holds out the possibility of lost patent scope as an inducement to potential patentees to produce socially valuable information early in the life of the patent.).

${ }^{51}$ Clarissa Long, Patent Signals, 69 U. Chi. L. Rev. 625, 625-28 (2002) (exploring the signaling function of patents generally, including the potential role of the patent document itself to convey information that would not be as credible when revealed in other contexts).

${ }^{52}$ Kieff, supra note 11, at 707-10 (explaining how the right to exclude use promotes commercialization by facilitating the social ordering and bargaining around inventions that are necessary to generate output in the form of information about the invention, a product of the invention, or a useful embodiment of the invention).

${ }^{53}$ Indeed, in addition to the administrability or screening problem discussed supra note 29 , another central problem the commercialization theory identifies in the reward theories is the failure of rewards to achieve commercialization. Id. at 717-18, 727-41 (discussing Harold Demsetz, Toward a Theory of Property Rights, 57 Am. Econ. Rev. 347 (1967), and Harold Demsetz, The Private Production of Public Goods, 13 J.L. \& Econ. 293 (1970)). The commercialization theory may resemble some aspects of the prospect theory. See id. at $707 \mathrm{n} .47$ ("The incentive to commercialize theory discussed herein is similar in some respects to the 'prospect' theory elucidated by Kitch, which views the patent as important in providing incentives for investment in increasing the value of a patented technology.") (citing Kitch, supra note 30, at 276-77). But Kitch focused on Barzel's work and on coordination as a tool to decrease pre-patent and post-patent rent-seeking, or what can be viewed as overuse of certain resources. See Kitch, supra note 30, at 265 (citing Barzel, supra note 30). In contradistinction, commercialization focuses on Demsetz's work and on coordination as a tool to prevent the underuse of certain resources. Kieff, supra note 11, at 717-18, 727-41 (citing work by Kitch and Demsetz). Although the earlier literature does suggest some correlation between these works of Kitch and Demsetz, it merely collects them together, without elucidating their interrelationships and differences. See, e.g., Julie E. Cohen, Lochner in Cyberspace: The New Economic Orthodoxy of "Rights Management," 97 Mich. L. Rev. 462, 497 n.121 (1998) (citing work by Demsetz and noting: "Similar reasoning underlies Edmund Kitch's proposed 'prospect' approach to patents."); Eisenberg, Experimental Use, supra note 6, at 1040 (citing work by Kitch and Demsetz and noting: "The prospect theory offers a justification for patents that is in keeping with broader 
determinations about the property right must be made early in the commercialization process for that process to occur. ${ }^{54}$ Indeed, as pointed out in this earlier work, the desire to help the commercialization of inventions was a central motivating factor behind the present patent system, which remains largely based on the 1952 Patent Act. ${ }^{55}$

To be sure, the commercialization view of the patent system, as elucidated thus far, may not be without its problems. First, as Abramowicz exhaustively explores in at least two of his present projects, there may be ways to modify the patent right to exclude so that commercialization is still achieved, while at the same time minimizing potential output-restricting effects of the strong right to exclude. ${ }^{56}$ Second, as Abramowicz also points out, the commercialization view may be both over- and under-inclusive. ${ }^{57}$ Stated differently, the commercialization view as

theories of property rights elaborated by Harold Demsetz ...."); Neil Weinstock Netanel, Copyright and a Democratic Civil Society, 106 Yale L.J. 283, 309 n.108 (1996) (citing work by Kitch and Demsetz and noting: "For neoclassicists, therefore, intellectual property is less about creating an artificial scarcity in intellectual creations than about managing the real scarcity in the other resources that may be employed in using, developing, and marketing intellectual creations."); Rai, supra note 6, at 121 n.236 (citing work by Kitch and Demsetz but seeing the underuse problem as "not readily apparent in the context of intellectual property"). At bottom, whereas the prospect theory can be seen to focus on coordination among competing users of an invention, the commercialization theory can be seen to focus on coordination among complementary users.

${ }^{54}$ This is because the property right is not serving a reward function or a simple costsubsidization function but rather is serving a coordination function. Kieff, supra note 11, at 712 ("Thus, as compared with a reward system, the patent system may be not only better able to improve coordination among market players engaged in the invention commercialization process, it also may be better able to avoid rent dissipation.") (citing generally Grady \& Alexander, supra note 31 ).

${ }^{55} I d$. at $736-46$ (showing how the drafters of the 1952 Patent Act were motivated by the commercialization theory).

${ }^{56}$ Abramowicz offers some important add-on tools for the patent system that would take the core rules for obtaining and enforcing patents as given, but at some point during the patent term buy out the patent right through a carefully crafted system to ensure the right price is paid. See Abramowicz, supra note 29, at 115-27; see also Michael Abramowicz, The Human Genome Project in Retrospect, in F. Scott Kieff, Perspectives on Properties of the Human Genome Project 231, 249-60 (2003) [hereinafter Perspectives on Properties] (describing and assessing a retrospective grant system).

${ }^{57}$ See Abramowicz, supra note 29, at 174. I also thank participants in the Spring 2001 Workshop Series of the John M. Olin Program in Law and Economics at the University of Chicago Law School for raising a similar objection. My response to both begins with a reminder of the brief discussion of the screening function in the paper on which they were commenting, see Kieff, supra note 11, at 712-17, and continues with the registration theory presented in this Article. 
discussed thus far does not fully explain, for example, why the patent system does not afford protection to help commercialize technologies that do not meet the tests for patentability, such as novelty, but nevertheless are not being commercialized presently. $^{58}$

The commercialization view does offer at least an implicit answer to this problem when it points out the screening role played by competitors of the patentee with the help of a court, a role which would have to be played by government decisionmakers under a reward system. ${ }^{59}$ Under the commercialization view, the competitors of the patentee are provided with incentives to bring information about a patent's validity to the attention of a decisionmaker. ${ }^{60}$ Accordingly, the Barnesandnoble.com case discussed at the beginning of this Article ${ }^{61}$ represents one example of the screening function contemplated by the commercialization view, albeit at a cost that is not insignificant. $^{62}$

Although the admittedly significant cost of screening patents through civil litigation presents a serious obstacle to any theory that embraces a soft-look approach, especially registration, these costs must be compared against the costs of

58 These might be technologies that have been forgotten, that never managed to draw sufficient coordinated interest to have been commercialized, or have been commercialized only outside of this country. Indeed, although so-called "patents of importation" were available for inventions not previously commercialized in the realm in England and in the colonies before the country was established, they essentially have not been allowed in this country since its inception. See generally Edward C. Walterscheid, Novelty in Historical Perspective (pts. 1-2), 75 J. Pat. \& Trademark Off. Soc'y 689, 777 (1993) (discussing history of the novelty provision in the U.S. patent system at the time of framing). The law and economics of the novelty provisions in the present patent system, including the treatment of foreign activity as prior art, are discussed infra Part III.A.1.

${ }^{59}$ Kieff, supra note 11 , at 712-17.

${ }^{60} I d$. It appears that Kitch also may have noticed this feature of the patent system in his reply to McFetridge and Smith:

A patent system is a grant system with the clever feature that it generates private incentives for those with comparative advantage in the innovating activity to reveal the information necessary to define the prospect right. Without this incentive, the granting agency would have to determine the appropriate scope and technological area of the prospect rights with access only to its own information.

Kitch, supra note 43, at 207 n.5. What is not clear from this text is whether "private parties" refers to patentees, the patentees' competitors, or both. As explained in more detail infra in Part III, each of these players in the patent system plays a crucial role in making sure the patent claim scope is "just right" in a way that minimizes social costs.

${ }^{61}$ See supra notes 1-4 and accompanying text.

${ }^{62}$ See supra note 4 (showing representative costs). 
allocating or screening patents using other approaches. ${ }^{63}$ As shown more fully below, by exploring the hypothetical model registration system, the registration theory offers comparatively practicable and inexpensive tools for screening patents. $^{64}$ The registration theory's emphasis on the notice aspect of the patent system is in keeping with contemporary theory of property rights, generally. ${ }^{65}$

\section{THE REGISTRATION MODEL}

Many patent critics would begin their reform efforts by ratcheting up the level of scrutiny given to patent applications during Patent Office examination to avoid the social costs due to those patents that ultimately would be adjudicated invalid through federal court litigation. ${ }^{66}$ The registration model, explored more fully below, shows that the level of scrutiny the Patent Office gives patent applications should be ratcheted down, because the cost of thorough examination would be higher than the costs of federal court litigation. ${ }^{67}$

The hypothetical model patent system differs from our present one in that patent applications would be merely registered in the Patent Office rather than examined. ${ }^{68}$ Under the present system, patent applications are filed in the Patent Office and examined for compliance with the legal rules for patentability by technically and legally trained staff of that administrative agency. ${ }^{69}$ Under the

63 See supra note 8 and accompanying text (discussing importance of comparative analysis). The advantages of screening under a soft-look approach, which were identified by the commercialization theory, bring into question the role of the Patent Office in a way that provides the impetus for the registration theory explored here. See supra notes 58-62 and accompanying text (citing Kieff, supra note 11, at 712-17). Thus, the registration theory can be seen as a companion to, or application of, the broader commercialization theory, which motivated the framing of the present patent system. See supra note 52 (summarizing commercialization theory).

${ }^{64}$ See infra Part II for discussion of the registration model itself and infra Parts III-IV for application of the model to our present patent system, including proposed reforms.

${ }^{65}$ See, e.g., Thomas W. Merrill \& Henry E. Smith, Optimal Standardization in the Law of Property: The Numerus Clausus Principle, 110 Yale L.J. 1, 24-70 (2000) (discussing informationcost theory of property).

${ }^{66}$ For sources, see supra note 5 and Lemley, supra note 6, at 1495 n.1.

67 See infra notes 75-84 and accompanying text (discussing costs of providing and evaluating the information needed to determine validity over the prior art).

${ }^{68}$ This involves a shift to a soft-look approach that is counter to the suggested shifts in the literature. For sources arguing for harder look, see supra note 5 and Lemley, supra note 6, at 1495 n.1.

69 The extent to which the Patent Office is like other administrative agencies, and therefore subject to the body of administrative law, has been a topic of substantial debate over the past several years in the literature and in the case law. Compare, e.g., Orin S. Kerr, Rethinking Patent Law in the Administrative State, 42 Wm. \& Mary L. Rev. 127, 127-33 (2000) (arguing that 
examination process, also called patent prosecution, the ex parte exchange between the applicant and the Patent Office examiner typically lasts about three years before an application that has not been either finally rejected or abandoned issues as a patent. $^{70}$ Having been examined, issued patents enjoy a procedural and substantive presumption of validity, and a party challenging a patent must prove invalidity under the heightened standard for civil litigation of "clear and convincing evidence." $" 71$

In the proposed registration model, patent applications would be filed with the Patent Office but not examined. The Patent Office would maintain original files and make authentic copies available publicly, perhaps via the web for free, as is done with the EDGAR system for securities filings at the Securities and Exchange Commission. ${ }^{72}$ In addition, the presumption of validity would be eliminated, or at

administrative law doctrines should not apply to patent law), with Craig Allen Nard, Deference, Defiance, and the Useful Arts, 56 Ohio St. L.J. 1415 passim (1995) (arguing that administrative law doctrines such as "Chevron deference" should be applied to Patent Office decisions). Also compare Dickinson v. Zurko, 527 U.S. 150, 152 (1999) (holding that contrary to almost a century of practice, the Administrative Procedures Act's standard-of-review provisions set forth in 5 U.S.C. $\$ 706$ do apply to factual determinations of the Patent Office), with Merck \& Co. v. Kessler, 80 F.3d 1543, 1549-50 (Fed. Cir. 1996), in which the U.S. Court of Appeals for the Federal Circuit stated the following:

\begin{abstract}
As we have previously held, the broadest of the [Patent Office]'s rulemaking powers - 35 U.S.C. $\S 6(a)$-authorizes the Commissioner to promulgate regulations directed only to "the conduct of proceedings in the [Patent Office];" it does not grant the Commissioner the authority to issue substantive rules. Because Congress has not vested the Commissioner with any general substantive rulemaking power, the "Final Determination" at issue in this case cannot possibly have the "force and effect of law." Thus, the rule of controlling deference set forth in Chevron does not apply.
\end{abstract}

(footnotes and internal citations omitted) (holding that the Patent Office is not entitled to the deference given other administrative agencies, which are vested with sufficient power by Congress, under the U.S. Supreme Court's decision in Chevron, USA, Inc. v. Natural Res. Def. Council, Inc., 467 U.S. 837, 842-45 (1984)).

${ }^{70}$ See, e.g., Chisum et al., supra note 6, at 91-128 (describing examination procedures under present system).

7135 U.S.C. $§ 282$ (2000) (presumption of validity).

72 See SEC Filings \& Forms (EDGAR), at http://www.sec.gov/edgar.shtml (last visited Nov. 13, 2003). As described on the front SEC web page about EDGAR:

All companies, foreign and domestic, are required to file registration statements, periodic reports, and other forms electronically through EDGAR. Anyone can access and download this information for free. Here you'll find links to a complete list of filings available through EDGAR and instructions for searching the EDGAR database.

Id. A modest filing fee, say $\$ 1,000$, might also be used to fund the operation, and to provide some disincentive against the filing of complete junk. Indeed, regular maintenance fees might also be required. See William M. Landes \& Richard A. Posner, Indefinitely Renewable Copyright, 70 U. Chi. L. Rev. 471, 472-75 (2003) (suggesting modest filing and maintenance fees as an efficient tool for managing a system of copyright registration and potentially infinite copyright term). 
least relaxed, thereby allowing invalidity to be judged under the standard ordinarily used in civil litigation of "a preponderance of the evidence."73

Recent work by Mark Lemley sheds some light on the strengths of softlook systems - such as the present system and the proposed registration modelas compared with hard-look systems in which patents are examined with stricter scrutiny. ${ }^{74}$ Lemley shows that "[b]ecause so few patents are ever asserted against a competitor, it is much cheaper for society to make detailed validity determinations in those few cases than to invest additional resources examining patents that will never be heard from again.",75

Lemley explores one important reason why the making of detailed validity determinations in litigation instead of in the Patent Office leads to lower net costs across all patents when he offers the core insight that litigation and its threat operate to provide important information about society's level of interest in a given patent - only those patents that matter receive a hard look. ${ }^{76}$ But this information could be provided through other means, perhaps even directly to the Patent Office, which leaves open the issue of which method of providing this information is cheapest. ${ }^{77}$

A more complete exploration of this open issue is therefore required to understand the many reasons why the costs of providing such information through litigation are less. ${ }^{78}$ One advantage of litigation is that, because it comes later, it allows more information about society's interest in the patent to accrue, thereby decreasing the likelihood of error associated with ex ante efforts to predict which

${ }^{73}$ Cf. supra note 71 (citing higher presumption of validity under current system).

${ }^{74}$ See generally Lemley, supra note 6.

${ }^{75}$ Id. at 1497. Merges also makes this argument in Robert P. Merges, As Many as Six Impossible Patents Before Breakfast: Property Rights for Business Concepts and Patent System Reform, 14 Berkeley Tech. L.J. 577, 594-96 (1999).

76 Lemley, supra note 6, at 1497 (deriving its essential insight from the littleacknowledged fact that the overwhelming majority of patents are never litigated or even licensed).

77 The screening function identified by the commercialization theory suggests the registration approach offered here. See supra notes 57-64 and accompanying text (discussing genesis of registration theory). For a discussion of strategies for bringing this information to the Patent Office, instead of to courts, see the discussion infra Part IV.D of systems that employ strategies that are soft-look/hard-look hybrids through various post-issuance procedures before the Patent Office.

${ }^{78}$ This is the focus of the registration theory, as discussed throughout this Article. For a discussion of the law and economics of the patent-obtaining rules of the present system and why they make sense under the registration theory because they are cheap to enforce, see infra Part III. For a discussion of potential improvements that may further decrease social costs, see infra Part IV. 
patents should receive close attention. ${ }^{79}$ Another advantage is that ex post selection of those patents that turn out to matter raises fewer administrative and public choice problems than would ex ante efforts because the attention of both proponents and opponents of a given patent are more likely to be at a peak in later litigation. ${ }^{80}$ Decision making through litigation mitigates many of the well-known problems associated with making award-type decisions. ${ }^{81}$

This Article makes a radical departure from prior work in the field by showing how, on an individual-patent basis, the costs of providing the information needed to decide validity and the costs of "correct" adjudication with that information are likely to be lower if these determinations are made in litigation than if they are made in patent examination. ${ }^{82}$ The intuition for this view is that the information relating to validity in litigated cases is rarely in the hands of the government but, rather, is often obtainable by, or in the hands of, a private party who experiences a strong incentive to bring that information to the attention

${ }^{79}$ This is essentially the Lemley insight. See Lemley, supra note 6, at 1497.

${ }^{80}$ A central problem explored in the public choice literature is ensuring the proper timing of decision making so that those most interested will be able to have their views counted. To be sure, this analysis must be seen against the background of the extensive literature on public choice theory. For collections of views and sources, see generally Perspectives on Public Choice (Dennis C. Mueller ed., 1997); Mueller, supra note 32; Maxwell L. Stearns, Public Choice and Public Law (1997); Mark Kelman, On Democracy-Bashing: A Skeptical Look at the Theoretical and "Empirical" Practice of the Public Choice Movement, 74 Va. L. Rev. 199 (1988); Dwight R. Lee, Politics, Ideology, and the Power of Public Choice, 74 Va. L. Rev. 191 (1988); Jonathan R. Macey, Transaction Costs and the Normative Elements of the Public Choice Model: An Application to Constitutional Theory, 74 Va. L. Rev. 471 (1988).

A related concern from the law and economic literature on patents is the importance of being able to know ex ante or at least early in the life of a patent whether the patent will be valid. See supra notes 50-52 and accompanying text (discussing the importance of ex ante approaches). But see supra note 56 (discussing the importance of ex post approaches in Abramowicz's work on retrospective spending).

${ }^{81}$ See Kieff, supra note 11, at 713-14 \& n.77 (citing Leo Katz, Ill-Gotten Gains: Evasion, Blackmail, and Kindred Puzzles of the Law 200 (1996) and discussing the problems with allocating cash rewards, tax credits, or any other kind of kudos in comparison to those with allocating patents and showing why systems of cash rewards or tax credits would be poor substitutes for a patent system).

${ }^{82}$ Whereas the Lemley insight looks to the aggregate cost across all patents, and points out that most patents turn out not to matter, see Lemley, supra note 6, at 1497, the insight provided in this Article looks at the cost for each patent that turns out to matter. For a discussion of the law and economics of the patent-obtaining rules when applied to any one patent, see infra Part III. These two insights may be combined to reveal the benefits of many of the proposed reforms discussed infra Parts IV.C-E. 
of a court. ${ }^{83}$ As discussed more fully below, this information is more cheaply obtained, provided, and evaluated by private parties, including the patentee and competitors of the patentee, than by the government. ${ }^{84}$

${ }^{83}$ Kieff, supra note 11, at 712-14 (discussing the role of a patentee's competitors in policing the patent system by searching out and bringing to bear the best information regarding a patent's validity).

A somewhat similar tool for bringing to bear this information is the bounty system proposed in John R. Thomas, Collusion and Collective Action in the Patent System: A Proposal for Patent Bounties, 2001 Univ. Ill. L. Rev. 305, 340-53. But such bounty systems may not be net improvements. They may provide some help in cases where the validity-destroying information is in the hands of someone other than the party seeking to invalidate the patent. But they may not be needed and raise further problems. To the extent the person having the information is subject to the jurisdiction of the courts, then that person is subject to the courts' subpoena power and can be compelled to produce documents, testimony, or other evidence once uncovered by the party seeking to invalidate the patent. The creation of a side market for these people to "sell" their information will frustrate the operation of the present systems that courts have developed for obtaining such information through third-party discovery. To the extent third-party witness compensation practices are considered so stingy that they provide a disincentive to these people, they can be made more flush through modest amendment to the rules of procedure in such cases.

An alternative approach is the effort to create higher incentives for the patent applicant to bring this information to bear during the patent examination process in the first instance as suggested in Jay P. Kesan, Carrots and Sticks to Create a Better Patent System, 17 Berkeley Tech. L.J. 763, 767-70, 787-97 (2002) (building upon and citing the fee-shifting techniques presented in the early working paper version of this Article, see F. Scott Kieff, Comments Regarding Competition \& Intellectual Property, Summary of Proposed Testimony, at 12-13, at http://www.ftc.gov/os/comments/intelpropertycomments/harvardlaw.pdf (2001) (last visited Nov. 13, 2003); infra text accompanying notes 280-282, but arguing that they should be used to provide an incentive for the patent applicant to better inform the patent examination process, which differs from the argument presented here in that it adheres to the orthodoxy of advocating methods for improving hard-look examination systems and eschews soft-look approaches like those explored in this work), and Shubha Ghosh \& Jay Kesan, What Do Patents Purchase? In Search of Optimal Ignorance in the Patent Office 2-5 (Univ. of Ill. Coll. of Law, Ill. Law \& Econ., Research Paper Series No. LE03-007, 2003), at http://papers.ssrn.com/pape.tar?abstract_id=410545 (arguing that Patent Office examination of patent applications, especially better informed examination, is important in making issued patents more valuable as the objects of licensing deals). But, as discussed infra Part III.A, the rules relating to patent validity are, and should be, responsive to information that happens to be not known or easily knowable by the patent applicant. As a result, heaping added incentives to find this information on the back of the patent applicant is not likely to be an efficient tool for bringing this information to the attention of decisionmakers. For other bounty approaches, see Joseph Scott Miller, Building a Better Bounty: Litigation-Stage Rewards for Defeating Patents 7-9 (2003) (working paper, available online at http://ssrn.com/abstract=431242) (suggesting cash rewards be granted to those who successfully defeat the validity of a patent).

Yet another approach is to alter the framework for appellate review of patent cases, as explored in the recent important work by Rai. See generally Arti K. Rai, Fact, Law, and Policy: An Allocation-of-Powers Approach to Patent System Reform (Univ. of Pa., Inst. for Law \& Econ., 


\section{The LAW \& ECONOMics OF PATENT-ObTAINING RULES}

The benefits of soft-look patent systems, like either the present system or the proposed registration model, can be seen through the below law and economic analysis of present patent-obtaining rules. Each major statutory requirement for patentability is studied, and its social-cost-minimizing qualities elucidated. ${ }^{85}$ Seen through this lens, otherwise puzzling aspects of the patent system appear for the first time to fit within a coherent normative framework, under which the positive law rules for obtaining patents operate primarily to minimize social cost. ${ }^{86}$

Not only does the registration theory depart from existing literature by accounting for the patent-obtaining rules, it also focuses on the verifiable claims of both a patent applicant and its competitors, instead of primarily on those of the applicant. ${ }^{87}$ That is, rather than first asking what scope of protection a patent applicant "deserves," patentee is entitled to the largest scope of protection that does not actually infringe the freedom from patent protection that some competitor of the patentee can claim

Research Paper No. 02-20, 2003), available at http://ssrn.com/ab-stract_id=335122 (advocating change in the appellate review process).

${ }^{84}$ See infra part III.A (reviewing patent-obtaining rules relating to the prior art, which turn out to be triggered by information that is in the hands of the specific parties the rules are designed to protect, not in the hands of the government). Merges makes a somewhat related point about the advantages private parties have over courts in evaluating information in patent cases in Robert P. Merges, Of Property Rules, Coase, and Intellectual Property, 94 Colum. L. Rev. 2655, 2664-65 (1994) (discussing private parties' informational advantage in negotiating over an intellectual property right, which will be based at least in part on the subsidiary question of that right's validity).

85 The rules are shown to practicably protect investment-backed expectations and facilitate ordering around protected territories. See infra Parts III.A-.A.3.

${ }^{86}$ The registration theory has explanatory power for the intricacies of these rules, which are not well explained by other law and economic theories of the patent system, like the prospect and rent dissipation theories. Those theories merely point out rent-seeking concerns that are implicated by patents and at best suggest that ex post determinations be made about which patents turn out to be better at decreasing the rent-seeking type of social cost. See supra notes 30-49.

87 In contradistinction, the claims of the patentee are the focus of so-called "reward" theories discussed infra notes 105-108.

${ }^{88}$ Other law and economics theorists have tried to align the benefit a patent confers on the patentee on the one hand with the benefit an invention confers on society on the other hand. See, e.g., Michael Kremer, Patent Buy-Outs: A Mechanism for Encouraging Innovation passim (Nat'l Bureau of Econ. Research, Working Paper No. 6304, 1997), at http://www.nber.org/papers/w6304 (discussing ways to improve the match between social surplus of the invention and the amount an inventor will recoup); Steven Shavell \& Tanguy van Ypersele, Rewards Versus Intellectual Property Rights passim (Nat'l Bureau of Econ. Research, Working Paper No. 6956, 1999), available at http:/www.nber. org/papers/w6956 (same). 
legitimately to "deserve," and provides a framework for judging this type of desert. ${ }^{89}$ In putting the burden on the competitor to justify freedom from the patent, this approach potentially leaves a patentee with what might be viewed as overly broad protection. ${ }^{90}$ But the theory also saddles the patentee with a strong incentive not to seek "too broad" protection and instead to get the scope "just right." 91 Under this view, as discussed more fully below, the patent-obtaining rules are comparatively easy-to-administer tools that operate, in the case of the prior art rules, to protect prior investment by third parties and patentees and, in the case of the disclosure rules, to facilitate their future investment. ${ }^{92}$

\section{A. The Prior Art Rules Inexpensively Protect Investment}

Patent law's rules regarding the prior art-the $\S 102^{93}$ and $\S 103^{94}$ requirements that a patentable invention be novel and nonobvious-protect the investment-backed expectations of both the patentee and its competitors, and they do so in ways that involve remarkably few administrative costs. ${ }^{95}$ As discussed more fully below, the novelty and nonobviousness requirements protect the investment-backed expectations of those other than the patentee by ensuring that a patent right to exclude will not extend to anything those in the art are doing

${ }^{89}$ The registration theory focuses on those claims that are verifiable, which turns out also to have strong explanatory power for the intricacies of the patent-obtaining rules relating to the prior art. See infra Part III.A. The more basic question of whether we should even elect to inject a patent system into the otherwise freer market is explored generally supra Part I, and the more specific case for a system of patents as property rights enforced by property rules is discussed in my earlier work on the commercialization theory as reviewed supra notes 11, 52-55.

${ }^{90}$ See supra note 6 (providing sources of criticism).

${ }^{91}$ The problem of getting patent scope "just right" has long dominated the literature. See generally Eisenberg, Experimental Use, supra note 6 (arguing for limited scope to protect competition rather than facilitate coordination); Grady \& Alexander, supra note 31 (offering rent dissipation theory to show how scope can be adjusted to control rent dissipation in both upstream and downstream research efforts); Kitch, supra note 30 (offering prospect theory to show how broad scope controls rent dissipation in downstream research efforts); Mark A. Lemley, The Economics of Improvement in Intellectual Property Law, 75 Tex. L. Rev. 989, 1000-05 (1997) (exploring economic impacts of scope); Robert P. Merges, Intellectual Property Rights and Bargaining Breakdown: The Case of Blocking Patents, 62 Tenn. L. Rev. 75 (1994) (same); Robert P. Merges \& Richard R. Nelson, On the Complex Economics of Patent Scope, 90 Colum. L. Rev. 839 (1990) (same). For a discussion of the patentee's incentives to get scope "just right," see infra Part III.C.

${ }^{92}$ See infra Parts III.A-B.

9335 U.S.C. $§ 102$ (2000) (novelty and statutory bars); see also infra Part III.A.1.

${ }^{94}$ Id. $\S 103$ (nonobviousness); see also infra Part III.A.2.

${ }^{95}$ See infra Parts III.A.1-2 (discussing how these rules account for verifiable investments). 
already or are about to do. ${ }^{96}$ As also discussed more fully below, the one-year grace period of the statutory bar protects the investment-backed expectations of the patentee. ${ }^{97}$

As Robert Nozick recognized in his watershed libertarian work on the minimalist state, it is because of patent law's prior art rules that the patent system does not run afoul of the Lockean proviso that property rights should leave enough in society's commons for those other than the property holder. ${ }^{98}$ Patent law achieves this effect by making sure that valid patents leave others free to do whatever they otherwise were doing. ${ }^{99}$

The registration theory goes further than the libertarian realization that patent law can have this minimal effect on the freedom of those other than the patentee by suggesting that this effect should not be merely a consequence of the patent system, but a goal. ${ }^{100}$ The registration theory also adds the goal of achieving this effect with the lowest administrative cost possible. ${ }^{101}$ Once these two relatively modest goals are envisioned, substantial light is shed on the justification and operation of the many otherwise complex positive law rules patent law has evolved for determining what counts as being in the prior art and

96 For a discussion of how the rules on novelty and nonobviousness protect these investments, see infra notes 127-134, 154-182 and accompanying text.

${ }^{97}$ For a discussion of the grace period, see infra notes 135-140 and accompanying text.

98 Robert Nozick, Anarchy State and Utopia 182 (1974) (noting that a patent does not deprive others of anything because, but for the act of inventing, the process or thing invented would not be in use); see also John Locke, The Second Treatise of Government § 27, in Two Treatises of Government 265, 288 (Peter Laslett ed., Cambridge Univ. Press 1988) (1690) (property rights are only justified "where there is enough, and as good left in the common for others"). The philosophy of intellectual property is a broad topic with its own literature. See, e.g., Wendy J. Gordon, A Property Right in Self-Expression: Equality and Individualism in the Natural Law of Intellectual Property, 102 Yale L.J. 1533 passim (1993) (exploring the case for the public's property interest in being free from intellectual property rights); Justin Hughes, The Philosophy of Intellectual Property, 77 Geo. L.J. 287, 296-330 (1988) (exploring the case for property rights in intellectual property using the Lockean labor approach); Jeremy Waldron, From Authors to Copiers: Individual Rights and Social Values in Intellectual Property, 68 Chi.-Kent L. Rev. 841 passim (1993) (exploring potential liberty restraints associated with intellectual property rights).

${ }^{99}$ Nozick, supra note 98 , at 182.

100 This goal is different from the goals of preventing rent-seeking or giving a reward, which are the goals of the prospect, rent dissipation, and reward theories offered by others. Compare supra notes 30-49 (discussing prospect and rent dissipation theories), with infra notes 105-108 (discussing reward theories).

101 The prospect, rent dissipation, and reward theories fail to offer any easy way to implement their goals. Compare supra notes 30-49 (discussing prospect and rent dissipation theories), with infra notes 105-108 (discussing reward theories). 
what preclusive effects it will have on a patent claim. ${ }^{102}$ Other patent theories fail to provide any explanation for core patent-obtaining rules about the prior art, fail to offer their own workable rules, or yield perverse results. ${ }^{103}$

Many patent theories try to answer the skeptical question raised about patents by one of the country's first luminaries to write about them. Thomas Jefferson, who as Secretary of State oversaw the administration of the country's first patent system, ${ }^{104}$ felt it important to ask whether each invention was in the first instance "worth to the public the embarrassment of an exclusive patent." 105 But any such theory that tries to tie the legitimacy of a patent to the nature of the invention faces a number of remarkably difficult problems. ${ }^{106}$ Theories tied to the merit of the invention face the conceptual problems of requiring some preliminary determination of how to judge merit in any practicable fashion. ${ }^{107}$ They also turn out to have faced serious practical problems concerning their application, as courts

${ }^{102}$ See infra Parts III.A.1-4 (discussing operation of these rules).

103 See supra notes 46-49 (prospect and rent dissipation theories do not offer workable rules); supra note 81, infra notes 106-108 (reward theories do not offer workable rules either).

${ }^{104}$ President George Washington signed the Patent Act of 1790 into law on April 10, 1790. Act of Apr. 10, 1790, ch. 7, 1 Stat. 109. See Kenneth W. Dobyns, The Patent Office Pony: A History of the Early Patent Office 21-22 (1994) (reviewing history of the Patent Office and collecting sources).

105 Letter from Thomas Jefferson to Isaac McPherson (Aug. 13, 1813), reprinted in Jefferson Writings 1286, 1292 (Merrill D. Peterson ed., 1984). Interestingly, Jefferson's views on patent issues may have been taken substantially out of context by many, including the Supreme Court:

[T] here is nothing whatever to indicate that the views held by Jefferson were those of the Framers themselves or those of either the first federal Congresses or the early federal judiciary, or, for that matter, the general populace. In this regard, the Graham Court completely ignored the rejection by the second federal Congress of Jefferson's proposal that a good defense to infringement should be that the invention "is so unimportant and obvious that it ought not to be the basis of an exclusive right."

Edward C. Walterscheid, "Within the Limits of the Constitutional Grant": Constitutional Limitations on the Patent Power, 9 J. Intell. Prop. L. 291, 325 (2002) (footnotes omitted) (collecting sources) (citing Graham v. John Deere Co., 383 U.S. 1, 10 (1966) (consolidated with Calmar, Inc. v. Cook Chem. Co., and Colgate-Palmolive Co. v. Cook Chem. Co.) and companion to United States v. Adams, 383 U.S. 39 (1966)).

106 Theories like this are generally referred to as "incentive-to-invent" or "reward" theories. See generally supra notes 27, 81 (collecting sources that review these theories and their pitfalls).

107 The conceptual problems generally involve a mismatch between any particular metric of merit and our impressionistic view of the "right" result. For example, if the metric were hard work, then accidental inventions would not be patentable. If the metric were value of the invention to society, then determinations cannot be made ex ante. The many conceptual problems associated with measuring rewards are discussed in the sources cited supra note 81 . 
applying these approaches tended to avoid finding that any invention met the standard. ${ }^{108}$

Some other patent theories suggest that the patent-obtaining rules should be adjusted to be sensitive to complex economic factors, like rent dissipation. ${ }^{109}$ But some of these, like the prospect theory, fail to offer concrete rules usable ex ante to make determinations of patentability and instead just offer general guidelines, such as that patent claims can be better if broader. ${ }^{110}$ Others, like the rent dissipation theory, offer the perverse recommendation that an invention that is so far beyond the prior art that it is "optimal" should not be patentable under the prior art rules because a patent would both cause too much rent dissipation among

108 By the late 1940s, courts would only allow a patent on an invention that they determined met the self-referential standard of "invention," a test that had become so overly robust that Justice Robert Jackson criticized its application in a 1949 dissent: "the only patent that is valid is one which this Court has not been able to get its hands on." Jurgensen v. Ostby \& Barton Co., 335 U.S. 560, 572 (1949) (Jackson, J., dissenting); see also Giles S. Rich, Congressional Intentor, Who Wrote the Patent Act of 1952?, in Patent Procurement and Exploitation (Southwestern Legal Found. ed., 1963), reprinted in Nonobviousness-The Ultimate Condition of Patentability, supra note 38 , at 1:1, 1:3 (discussing history of the nonobviousness requirement, and its use as a replacement for the requirement of invention); George M. Sirilla, 35 U.S.C. $\$ 103$ : From Hotchkiss to Hand to Rich, the Obvious Patent Law Hall-of-Famers, 32 J. Marshall L. Rev. 437 passim (1999) (same). Even after the requirement for "invention" was statutorily replaced by the 1952 Patent Act's requirement for nonobviousness in $\S 103$, some courts continued to apply a standard remarkably similar to the one criticized by Justice Jackson. Gerald J. Mossinghoff, Side Bar: The Creation of the Federal Circuit, in Principles of Patent Law, supra note 6, at 30, 30-31 (former Patent Office Commissioner Mossinghoff explaining importance of creating the U.S. Court of Appeals for the Federal Circuit in 1982 to bring uniformity to the application of patent law and avoid the results in some circuits, as discussed during the confirmation hearings for thenSecond Circuit Judge Thurgood Marshall's nomination to the Supreme Court when he responded to a question about patents by saying "I haven't given patents much thought, Senator, because I'm from the Second Circuit and as you know we don't uphold patents in the Second Circuit"). Patent theories like these are more about the absence of patents than about how or why we want patents to operate.

109 The prospect and rent dissipation theories discussed earlier are two prime examples. See supra Part I. The commercialization theory also discussed earlier differs from these two theories in viewing the coordination effects of the patent not as a way to prevent rent-seeking or rent-dissipating behavior but only as a way to facilitate the industrial organization activities necessary to get the public to enjoy some benefit from a nascent invention. See supra notes 52-55 and accompanying text. The modest roles for the positive law prior art rules that are contemplated in the registration theory discussed here are entirely compatible with the commercialization theory and its views on the screening function played by competitors of the patentee. See supra notes 5255 and accompanying text.

${ }^{110}$ See supra Part I; see also Kitch, supra note 30, at 267-71 (discussing importance of broad claims early after initial discovery). 
those seeking the patent and not be needed to prevent rent dissipation among those who otherwise would race to improve upon it. ${ }^{111}$

In contradistinction, the registration theory views the prior art rules as designed to achieve the more modest goals of protecting investment-backed expectations based on objective verifiable evidence, which is an approach that is both workable and has explanatory power for the present system. ${ }^{112}$ The registration theory begins from a presumption in favor of holding inventions to be patentable over the prior art unless some verifiable evidence of sufficient reliance is shown. ${ }^{113}$ Under this view, the system should have a novelty requirement to protect those investments that have matured into actual technical activities. ${ }^{114}$ Similarly, the system should have something like a nonobviousness requirement to protect those investments that are about to mature into actual technical activities. $^{115}$ For both requirements, the system should consider only those investments that verifiably existed before those of the one claiming a patent right. ${ }^{116}$

The registration theory has great explanatory power for the prior art rules. $^{117}$ The theory's presumption in favor of not holding an invention unpatentable over the prior art explains the often-overlooked introductory language to the statutory prior art provisions, which sets forth that "[a] person shall be entitled to a patent unless" any of the conditions subsequently provided in the statute is triggered. ${ }^{118}$ Indeed, the registration theory also explains the

111 Grady \& Alexander, supra note 31, at 346 ("By definition, an optimal proportion cannot be improved upon; rent dissipation theory, therefore, predicts patent nonenforcement."). In part, the rent dissipation theory seems to be assuming that something may actually be "optimal" or "good" in a way that assumes a great deal. Most importantly, it seems to implicitly subscribe to some type of nirvana thesis, which is generally shunned in the literature because no example has been offered of any human endeavor that is in all respects "optimal." See supra note 8 (critiquing nirvana approaches).

112 Compare supra notes 46-49 (prospect and rent dissipation theories do not offer workable rules), with supra note 81, and infra notes 106-108 (reward theories do not offer workable rules either).

${ }^{113}$ Unlike the theories that focus on determining which claims to a patent are worth protecting, the registration theory focuses on determining which claims to freedom from patent are worth protecting.

${ }^{114}$ See infra Part III.A.1.

115 See infra Part III.A.2.

${ }^{116}$ See infra notes 141-143 and accompanying text (discussing how dates are compared).

${ }^{117}$ See infra Parts III.A.1-4 (discussing the rules).

11835 U.S.C. $\S 102$ (2000). The many subsections of $\S 102$, subsections (a) through (g), then set forth the categories of things that can count as prior art. Any single piece of prior art, sometimes also called a "reference," will count as prior art for purposes of both the novelty and 
otherwise controversial statutory language that provides such a minimal role for the Patent Office. ${ }^{119}$ In addition, present patent-obtaining prior art rules have been considered by many, including me, to be "a statutory mine field through which patent applicants must navigate." ${ }^{, 120}$ With the benefit of the registration theory, they can be seen as the expected intricacies of a system rationally designed to consider all verifiable investments. ${ }^{121}$

What is more, the registration theory's look to these prior art rules as being triggered by relatively simple fact questions into the existence or nonexistence of specific things or events reveals why it makes sense for patent validity determinations to be made by the same ordinary civil judges and juries that decide other cases. Determinations about what people verifiably have done or are about to do implicate surprisingly simple questions of fact that do not require

statutory bar analyses of $\S 102$ and the nonobviousness analysis of $\S 103$ if it is determined to trigger any one, or more than one, of the subsections of $\S 102$. Chisum et al., supra note 6 , at 554; see also In re Foster, 343 F.2d 980, 984-90 (C.C.P.A. 1965) (overruling In re Palmquist, 319 F.2d 547 (C.C.P.A. 1963) to hold that despite plain meaning of the statute, art qualifying only under $\S 102$ (b) may support an analysis under $\S 103$ ). For the reasons discussed more thoroughly by Parchomovsky and Lichtman et al., the result in Foster is important to mitigate the costs associated with strategic disclosure. See generally Douglas Lichtman et al., Strategic Disclosure in the Patent System, 53 Vand. L. Rev. 2175 (2000); Gideon Parchomovsky, Publish or Perish, 98 Mich. L. Rev. 926 (2000).

${ }^{119}$ See supra note 69 (citing Merck \& Co. v. Kessler, 80 F.3d 1543, 1549-50 (Fed. Cir. 1996) (holding that because "the broadest of the [Patent Office's] rulemaking powers-35 U.S.C. $\S 6(\mathrm{a})$-authorizes the Commissioner to promulgate regulations directed only to "the conduct of proceedings in the [Patent Office];' it does not grant the Commissioner the authority" needed to in turn entitle the Patent Office to the deference given other administrative agencies, which are vested with sufficient power by Congress, under the Supreme Court's decision in Chevron, USA, Inc. v. Natural Res. Def. Council, Inc., 467 U.S. 837, 842-45 (1984)).

${ }^{120}$ See, e.g., Chisum et al., supra note 6, at 323.

${ }^{121}$ See infra Parts III.A.1-4. What is more, in accordance with the registration theory's goal of improving efforts to protect investments, many of these rules worked their way into our regime over time even though they were not all present at the outset. See generally P.J. Federico, Commentary on the New Patent Act, in Title 35, United States Code Annotated 1 (West 1954), reprinted in 75 J. Pat. \& Trademark Off. Soc'y 161 (1993) (reviewing history and operation of our present patent system, which is largely based on the 1952 Patent Act); Edward C. Walterscheid, The Ever Evolving Meaning of Prior Art (pts. 1-3, 4-6, 7-8, \& pt. 9), 64 J. Pat. \& Trademark Off. Soc'y 457, 571, 632 (1982), 65 J. Pat. \& Trademark Off. Soc'y 3, 477, 658 (1983), 66 J. Pat. \& Trademark Off. Soc'y 479, 573 (1984), 67 J. Pat. \& Trademark Off. Soc'y 33 (1985) (reviewing in detail the evolution of many of the prior art provisions that exist since the 1952 Patent Act and collecting sources); Walterscheid, supra note 58 (reviewing the first roughly 100 years of the prior art provisions with particular focus on the rules relating to derivation and foreign use). 
special technological training or judgment, and therefore are well suited for adjudication by lay juries and judges. ${ }^{122}$

\section{Novelty and Bar}

The patent system's patent-obtaining rules relating to the prior art begin with those in $\S 102$ of the statute, which relate to novelty and bar. ${ }^{123}$ "Anticipation by the prior art" is the phrase in patent law used to describe the case where a patent claim is directed to subject matter that is not new. "Statutorily barred" is the phrase in patent law used to describe the case where a patent claim is directed to subject matter that, even if new at the time of invention, was exposed to the public more than a year before the application was filed. ${ }^{125}$ The registration view

${ }^{122}$ F. Scott Kieff, How Ordinary Judges and Juries Decide the Seemingly Complex Technological Questions of Patentability over the Prior Art, in Perspectives on Properties, supra note 56 , at 471,473 . Such a positive view of lay juries in patent cases marks a somewhat counterintuitive departure from most of the other work in this field, including earlier work of my own. See, e.g., S. Leslie Misrock and F. Scott Kieff, Latent Cures for Patent Pathology: Do Our Civil Juries Promote Science and the Useful Arts?, presentation at The Crisis of Science and the Law, Science in Crisis at the Millennium (an International Symposium), The George Washington University Center for History of Recent Science (Sept. 19, 1996), in Principles of Patent Law, supra note 6, at 1024, 1024-38; see also, e.g., Kimberly A. Moore, Judges, Juries, and Patent Cases-An Empirical Peek Inside the Black Box, 99 Mich. L. Rev. 365, 365 n.2 (2000) (collecting sources on "extensive scholarly debate and increasing skepticism regarding the role of juries in patent cases").

12335 U.S.C. $\$ 102$ (2000) (“Conditions for patentability; novelty and loss of right to patent"). The mention in $\S 101$ of the word "new" has not been read to provide any separate novelty requirement. See Federico, supra note 121, at 178 ("The general part of the Committee Report states that section 102 "may be said to describe the statutory novelty required for patentability, and includes, in effect, an amplification and definition of "new" in section 101"'); see also In re Bergy, 596 F.2d 952, 960 (1979) ("Notwithstanding the words 'new and useful' in $\S 101$, the invention is not examined under that statute for novelty because that is not the statutory scheme of things or the long-established administrative practice."), dismissed as moot, 444 U.S. 1028 (1980).

124 The maxim setting forth the so-called "classic infringement test for anticipation," which also applies to analysis under the statutory bar, is "[t]hat which will infringe if later, will anticipate, if earlier." See Chisum et al., supra note 6, at 414 (citing Knapp v. Morss, 150 U.S. 221 (1893)). For more on how this test is applied in practice, see infra notes 141-150 and accompanying text.

${ }^{125}$ For a discussion of the bar, which also operates as a one-year grace period for filing, see infra notes 137-140. 
elucidates why it makes sense for the patent system to have evolved these doctrines in all their detail. ${ }^{126}$

In accordance with the registration view, printed publications describing a technology count as prior art under the novelty provisions because publicly available documents are good evidence of investment by their authors and of something on which others could rely. ${ }^{127}$ Any printed publication will count, even if in a foreign country, as long as it is verifiably the type of publication on which a member of the public could rely. ${ }^{128}$ Indeed, even pending patent applications that later issue as patents, but that are not yet published, count as prior art as of their filing date because their inventors have invested in the verifiable contents of these government-stored documents and those in confidential relationships with their inventors could rely on them as well. ${ }^{129}$

Similarly, uses of a technology only count as prior art if corroborated by someone other than the one claiming prior invention because verifiable public use

126 Compare supra note 48 and accompanying text (rent dissipation theory does not explain case law), with supra note 108 and accompanying text (reward theories do not explain case law).

${ }^{127}$ See 35 U.S.C. $§ 102(a)-(b)$ (referring to printed publications).

${ }^{128}$ See In re Hall, 781 F.2d 897, 898-900 (Fed. Cir. 1986) (counting a single cataloged student thesis at Frieburg University in Germany as prior art because it was, inter alia, physically available to the public); In re Cronyn, 890 F.2d 1158, 1161 (Fed. Cir. 1989) (not counting three student theses at an American university as prior art, even though they were physically accessible to the public, because there was no evidence they were logically accessible to the interested public by, for example, being indexed in the library's subject catalog). Under the registration theory these publications should count as prior art because they might lead to third-party reliance, not because they might somehow fairly be said to have been available to the patentee.

${ }^{129}$ See Alexander Milburn Co. v. Davis-Bournonville Co., 270 U.S. 390, 399-402 (1926) (Holmes, J.) (counting so-called secret prior art as prior art as of the application's filing date). The present version of this rule is codified in $\S 102(\mathrm{e})(2)$. See 35 U.S.C. $\S 102(\mathrm{e})(2)$. For the same reasons, an application filed in foreign patent offices will also count as prior art as of its filing date with one of the international Patent Cooperation Treaty-designated patent offices, if filed according to the procedural rules of the treaty, and as long as the application is eventually published in English and designates that it should be sent to the United States Patent Office. Id. Also for the same reasons, under $\S 102(\mathrm{e})(1)$, prior art effect is extended to pending applications that do not issue as a patent but do get published under the rule of publishing eighteen months after filing, which was part of the 1999 American Inventors Protection Act and is codified in $\S 122(\mathrm{~b}) . I d$. $\S \S 102(\mathrm{e})(1), 122(\mathrm{~b})$. Applications not published pursuant to $\S 122(\mathrm{~b})$, however, such as those abandoned, do not count as prior art. The authors of these documents are able to maintain their information as a trade secret but the documents themselves will not preclude patentability for others. To be sure, the use by these authors may in certain circumstances preclude patentability under $\S 102(\mathrm{a})$ or (g), as discussed infra at notes 130-132 and accompanying text. 
may induce investment in the technology by observers of this use. ${ }^{130}$ Although $\S 102$ (a) only expressly provides, in pertinent part, that the invention must not have been "known or used by others," the word "public" has been read into that statutory language through case law. ${ }^{131}$ Use that is not public, yet also is not abandoned, suppressed, or concealed, may also count as prior art under $\S 102(\mathrm{f})$ and $\S 102(\mathrm{~g})$, but only if corroborated by evidence other than inventor testimony.

Verifiable public use or sale sufficiently in advance of patent application filing, even if by the one seeking a patent, can count as prior art against that application under certain circumstances because it may induce investment in the technology by observers of this use. ${ }^{133}$ For this reason, the statutory bar provisions

${ }^{130}$ The registration protects against the risk of these investments being later subject to a patent right to exclude by enforcing the rule that they destroy patentability.

131 Gayler v. Wilder, 51 U.S. (10 How.) 476, 494-98 (1850) (not counting use of a technology relating to a safe as prior art unless it is accessible to the public). See 35 U.S.C. $\S 102$ (a).

${ }^{132}$ Section $102(\mathrm{f})$ is the provision governing cases of derivation, where the party claiming the patent right derived the claimed information from someone else. 35 U.S.C. $\S 102(f)$; see Gambro Lundia AB v. Baxter Healthcare Corp., 110 F.3d 1573, 1576-78 (Fed. Cir. 1997) (holding that $\S 102(\mathrm{f})$ prevents patentability if there can be shown to be both prior, corroborated, conception of the claimed invention, and its communication to the one claiming to be the first inventor). Where the prior inventor turns out to have sought its own patent, the Patent Office conducts something called an "interference proceeding," which is the quasi-litigation process initiated when a patent application claims the same subject matter as another application or an issued patent to determine who is the first inventor. Section $102(\mathrm{~g})$ is generally understood to govern interference proceedings but also has been held to be a provision under which information may be treated as prior art just like under the other subsections of $\S 102$. See 35 U.S.C. $\S 102(\mathrm{~g})$. See generally Chisum et al., supra note 6, at 441-51 (describing evolution of case law treating 35 U.S.C. $\S 102(\mathrm{~g})$ as a provision under which prior use may count as prior art even if not public, as long as it is not abandoned, suppressed, or concealed, as well as the amount of evidence needed to satisfy that provision). For more on the rules governing priority disputes, see infra Part III.A.3. Where the prior inventor turns out to have been outside the United States, the rules become more complicated, as discussed infra Part III.A.4. For more on why the use of priority of invention as a test to determine who wins a patent right as between two or more claimants makes more sense under the registration and commercialization theories than the use of filing date, because when invention date is used it is more likely that a valid patent claim will emerge than when filing date is used, see infra notes 183-186 and accompanying text.

${ }^{133}$ See 35 U.S.C. $\S 102($ b). The policy goal of protecting investment has been recognized in the case law associated with this prior art provision. See General Elec. Co. v. United States, 654 F.2d 55, 61 (Ct. Cl. 1981) ("First, there is a policy against removing inventions from the public [that] the public has justifiably come to believe are freely available to all as a consequence of prolonged sales activity.").

Often described as a statutory bar to the patenting of inventions publicized for more than a year, this provision operates to provide a one-year grace period for publicity that will not bar patentability. The grace period entered the U.S. patent system in 1839 as a period of "grace" 
treat sale or use in public by either the inventor or a third party as prior art against the inventor's claim to a patent. ${ }^{134}$

The patent system even protects the inventor's own investments to some extent through allowance of a one-year grace period in which to file a patent application before the on-sale and public use bars are triggered. This is important because a patent system in which there is no grace period may provide incentives for decreased rate of disclosure of new technologies, and a decrease in the overall value of patents. The decreased rate of disclosure under a system lacking a grace period would be due to the need to keep potentially patentable information unpublished before filing the patent application. ${ }^{135}$ The decrease in overall value of patents would be due to the fear of unknown but unavoidable pre-filing disclosures lurking in the history of every patent. ${ }^{136}$

But the inventor's own investments have to be balanced against the reasonable reliance interests of others. For this reason, the grace period is limited to one year, which allows others to rely on essentially any public evidence of a technology that is beyond the time of the grace period. ${ }^{137}$ As soon as an inventor's use of the technology becomes available to the public, ${ }^{138}$ or is on sale at any stage

lasting two years. Act of March 3, 1839, 5 Stat. 353. The period was shortened to one year in 1939. Act of August 5, 1939, Pub. L. No. 76-288, 53 Stat. 1212. It remains so in the present 35 U.S.C. $\S 102(b)$.

Not all patent systems in the world provide a statutory grace period, although it is not exactly clear whether most systems end up providing one through case law. See generally Joseph Straus, Grace Period and the European and International Patent Law (2001) (study commissioned by the European Patent Organization to examine whether European patent law should provide a pre-filing grace period) (collecting sources).

${ }^{134}$ See Baxter Int'l, Inc. v. COBE Labs., 88 F.3d 1054, 1058-59 (Fed. Cir. 1996) (thirdparty use may raise statutory bar).

${ }^{135}$ See Straus, supra note 133, at 80-81, 93 (discussing incentives to suppress publication under a regime of no grace period).

${ }^{136} I d$. at 95-96 (discussing decrease in value of patents under absolute novelty regimes, which do not have a grace period).

${ }^{137}$ Under the registration theory, the specific amount of time is arbitrary as long as it is fixed and knowable ex ante and as long as it is both long enough to allow some grace-period effect and not long enough to unduly frustrate investment in recently public technologies. For some history of the various grace periods, see supra note 133.

138 See Egbert v. Lippmann, 104 U.S. 333, 333-38 (1882) (holding use even in a private undergarment, here corset steels, can count as prior art). Compare Metallizing Eng'g Co. v. Kenyon Bearing \& Auto Parts Co., 153 F.2d 516, 517-20 (2d Cir. 1946) (Hand, J.) (use will count if it is commercial), with Elizabeth v. Pavement Co., 97 U.S. 126, 134 (1878) (use will not count if merely experimental). To whatever extent potential third-party reliance is a serious theoretical matter, actual third-party public use as in Baxter, 88 F.3d at 1058-59, counts as prior art because it shows actual reliance. 
past when it is "ready for patenting," the clock on the one-year window begins. ${ }^{139}$ The subsequent one year provides time for the inventor to decide whether to prepare and file a patent application, and then to take these steps if elected. ${ }^{140}$

Taken together, these rules about what counts as prior art allow every patent claim to be judged as of its "critical date" against a piece of prior art's "effective date." 141 The critical date is either the verifiable date of invention, or one year before the application's filing date, depending upon whether the invention is being analyzed for anticipation or bar. ${ }^{142}$ The effective date is the date the piece of prior art is allowed to count as prior art, as discussed above. ${ }^{143}$

Under $\S 102$, patentability is precluded if any single item that is determined to count as prior art under any single subsection of the statute is found to fully disclose the claimed invention. ${ }^{144}$ Importantly, case law has provided a remarkably easy test for determining whether an invention is fully disclosed for purposes of this analysis, which can be seen through the use of the schematic claim chart in Table 1, below. ${ }^{145}$

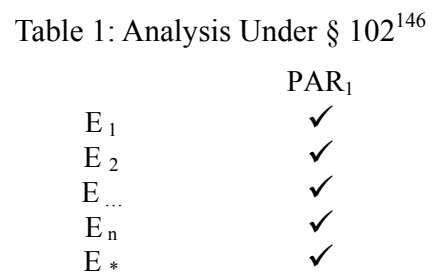

${ }^{139}$ Pfaff v. Wells Elecs., 525 U.S. 55, 67-68 (1998) (holding the year begins when the technology is "subject to a commercial offer for sale" and "ready for patenting"). III.A.3.

${ }^{140}$ The importance of taking the time to prepare a good application is discussed infra Part

${ }^{141}$ Chisum et al., supra note 6, at 326 (providing sample analysis using these terms).

${ }^{142}$ Anticipation occurs when the claimed invention is found to have been in the art that existed prior to the putative invention. See supra notes 118-132 and accompanying text. A statutory bar occurs when the application is not filed within one year of a bar-triggering event. See supra notes 133-139 and accompanying text.

143 This is either the date of use, publication, or filing, depending upon which part of $\S 102$ is triggered. See supra notes $118-132$ and accompanying text.

${ }^{144}$ See supra note 124 (discussing basic statement of test for anticipation).

${ }^{145}$ See infra notes 146-150 (discussing application of this test).

$146 E_{1}$ through $E_{n}$ represent the elements of the claim arbitrarily assigned numbers 1 through n. $E_{*}$ represents enablement of the entire claim. PAR1 represents any single prior art reference, such as a journal article, sample product, student thesis, etc. 
Table 1 compares the elements of a stylized claim against the prior art for a determination of potential unpatentability or invalidity under $\S 102 .{ }^{147}$ The substantive requirement for determining no valid patent claim under $\S 102$ is triggered only if a single prior art reference discloses, either expressly or under principles of inherency, each and every element of the claim, plus enablement. ${ }^{148}$ When mapped onto this table, this means that a proper holding of invalidity will

${ }^{147}$ The term invalidity refers to the failure of a claim in an issued and successfully examined patent to satisfy one of the substantive patent-obtaining rules. The term unpatentability refers to the failure of a claim in a patent application to satisfy one of the substantive patentobtaining rules. These terms are interchangeable if operating under a soft-look system like the registration model that does not involve any examination.

The representation of a claim as a listing of its several elements in claim charts like Table 1 has become so common in patent cases that the local rules of some courts that hear many patent cases, like the Northern District of California, have for some time required their use. Chisum et al., supra note 6, at 848-49 (discussing local rules for claim charts). The identification of these elements turns largely on the interpretation, or construction, of a patent claim, which is treated as a matter of law for decision by the court, and which is the first step in any analysis of either validity or infringement because the claim must be construed the same for both purposes. See generally id. at 829-73 (discussing the substantive and procedural law of claim interpretation after the Supreme Court decision in Markman v. Westview Instruments, Inc., 517 U.S. 370 (1996)). The great degree of debate over the law of claim construction itself injects a degree of uncertainty into this otherwise relatively crisp analysis. Recent empirical work by Wagner suggests that this uncertainty may lessen over time as the Federal Circuit develops predictable trends in its case law. See R. Polk Wagner \& Lee Petherbridge, Is the Federal Circuit Succeeding? An Empirical Assessment of Judicial Performance, 152 U. Penn. L. Rev. (forthcoming 2003), available at http://www.claimconstruction.com (discussing empirical work relating to trends in the Federal Circuit's law of claim construction) (last visited Nov. 13, 2003).

148 See Minn. Mining \& Mfg. v. Johnson \& Johnson, 976 F.2d 1559, 1565 (Fed. Cir. 1992) (Rich, J.) (invalidity under $\S 102$ is "a question of fact, and one who seeks such a finding must show that each element of the claim in issue is found, either expressly or under principles of inherency, in a single prior art reference"); In re Paulsen, 30 F.3d 1475, 1479 (Fed. Cir. 1994) ("In addition, the reference must be enabling and describe the applicant's claimed invention sufficiently to have placed it in possession of a person of ordinary skill in the field of the invention."); see also In re Robertson, 169 F.3d 743, 745 (Fed. Cir. 1999) ("To establish inherency, the extrinsic evidence 'must make clear that the missing descriptive matter is necessarily present in the thing described in the reference, and that it would be so recognized by persons of ordinary skill. Inherency, however, may not be established by probabilities or possibilities. The mere fact that a certain thing may result from a given set of circumstances is not sufficient." (citation omitted) (quoting Cont'l Can Co. v. Monsanto Co., 948 F.2d 1264, 1268, 1269 (Fed. Cir. 1991))). The inherency and enablement doctrines make sense under the registration theory because a disclosure may induce third-party reliance based upon its ability to enable those in the art to practice its teachings, even if those teachings do not contain all the words that might appear in some patent claim. What matters for purposes of such reliance is substance, not form. 
only lie if a check mark can be found as a matter of fact for every row. ${ }^{149}$ And to achieve a check mark there must be admissible evidence that as a matter of fact the pertinent content is present in the piece of prior art. ${ }^{150}$

Although this determination of novelty is relatively easy, the registration theory recognizes that it may not go far enough in that parties may invest in a technology before it fully exists. ${ }^{151}$ As a result, the patent system may have to go beyond merely requiring inventions be new, or not fully disclosed in a single prior art reference; it may also have to prevent valid patents from covering what anyone is investing towards, if such a determination can be made inexpensively. ${ }^{152}$ Under the registration theory, this is the role played by the nonobviousness requirement, discussed below. ${ }^{153}$

\section{Nonobviousness}

The patent system has long demanded something more than mere novelty when determining patentability over the prior art. This additional requirement is called "nonobviousness" in the present system. ${ }^{154}$ It has been given labels in previous systems that are as tautological as "the requirement for invention;" and its various forms have generated great difficulty for the courts for over a century. ${ }^{155}$ It also raises significant problems for the patent theories in the literature. $^{156}$

149 This represents the presence of each element in the claim, plus enablement, which as discussed in the case law supra note 148, is required for a finding of invalidity under $\S 102$.

${ }^{150}$ As discussed in the case law, supra note 148 , invalidity under $\S 102$ requires the prior art disclosure to be in a single reference.

${ }^{151}$ Indeed, the likelihood of these investments is logically closely tied to the presence in the art of a specific teaching, suggestion, or motivation to combine elements in the prior art to work towards the claimed invention. The registration view thereby provides a justification for the case law that requires these elements as part of a nonobviousness analysis. For more on the law of nonobviousness, see infra Part III.A.2.

152 The ultimate question of whether it goes far enough will turn on whether these investments can be efficiently identified and protected. As discussed infra in Part III.A.2, although it is clear that the nonobviousness test does a better job on this score than the former "requirement for invention," it is not entirely clear whether the case law relating to the test of nonobviousness has implemented the test optimally.

${ }^{153}$ See supra note 86 (the registration theory helps explain the intricacies of the patentobtaining rules whereas the other theories do not).

154 For history of the nonobviousness requirement in patent law, see generally Nonobviousness - The Ultimate Condition of Patentability, supra note 38; Sirilla, supra note 108.

${ }^{155}$ During the first half of the 1900s when called the requirement for invention, before the 1952 Patent Act, it had become known as "the plaything of the judiciary." Giles S. Rich, Why and How Section 103 Came to Be, in Nonobviousness-The Ultimate Condition of Patentability, 
The version of this requirement called nonobviousness was written into the patent system through the 1952 Patent Act to statutorily jettison the prior case law associated with the former, vague and anti-patent, requirement called "the requirement for invention." 157 Even the drafters of this new standard recognized that it did not, on its face, appear to be any more precise in application than the former requirement. ${ }^{158}$ Nevertheless, as the registration theory would predict, the

supra note 38, at 1:208. Even after Congress wrote the $\S 103$ nonobviousness into the statute in the 1952 Patent Act, over ten years passed before the Supreme Court applied the new standard of nonobviousness in Graham and its companion cases. 383 U.S. at 12-37 (consolidated with Calmar and Colgate-Palmolive); Adams, 383 U.S. at 48-52. For an inside look at the Graham decision, see Tom Arnold, Side Bar: The Way the Law of Section 103 Was Made, in Principles of Patent Law, supra note 6, at 549, 549-54. Soon afterwards, the Court re-injected confusion by writing about synergism and combinations. See Sakraida v. Ag Pro, Inc., 425 U.S. 273, 282 (1976) (holding patent invalid because it was a mere combination of old elements and had no synergistic effect); Anderson's-Black Rock, Inc., v. Pavement Salvage Co., 396 U.S. 57, 61 (1969) (holding patent invalid because "No such synergistic result is argued here"). These terms were not weeded back out of the law until the creation of the Federal Circuit in 1982. See Sirilla, supra note 108, at 543. As the Federal Circuit has reminded:

A requirement for "synergism" or a "synergistic effect" is nowhere found in the statute, 35 U.S.C. When present, for example in a chemical case, synergism may point toward nonobviousness, but its absence has no place in evaluating the evidence on obviousness. ...

The reference to a "combination patent" is equally without support in the statute. There is no warrant for judicial classification of patents, whether into "combination" patents and some other unnamed and undefined class or otherwise. Nor is there warrant for differing treatment or consideration of patents based on a judicially devised label. Reference to "combination" patents is, moreover, meaningless. Virtually all patents are "combination patents," if by that label one intends to describe patents having claims to inventions formed of a combination of elements. It is difficult to visualize, at least in the mechanical-structural arts, a "non-combination" invention, i.e., an invention consisting of a single element. Such inventions, if they exist, are rare indeed.

Stratoflex, Inc. v. Aeroquip Corp., 713 F.2d 1530, 1540 (Fed. Cir. 1983).

${ }^{156}$ See supra notes 30-49 and accompanying text (other theories merely point out rentseeking concerns that are implicated by patents and at best suggest that ex ante determinations be made about which patents turn out to be better at decreasing the rent-seeking type of social cost).

157 See generally Giles S. Rich, Laying the Ghost of the "Invention" Requirement, 1 Am. Pat. L. Ass'n Q.J. 26 (1972), reprinted in Nonobviousness-The Ultimate Condition of Patentability, supra note 38, at 1:501 [hereinafter Rich, Laying the Ghost] (discussing the great lag between the arrival of the new standard in the statute and its adoption by the courts); Giles S. Rich, The Vague Concept of "Invention" as Replaced by Section 103 of the 1952 Patent Act, $46 \mathrm{~J}$. Pat. Off. Soc'y 855 (1964), reprinted in Nonobviousness-The Ultimate Condition of Patentability, supra note 38, at 1:401 (Judge Rich's speech upon receipt of the Kettering Award in which he discusses the role of nonobviousness in $\S 103$ as the replacement for the so-called requirement for invention).

158 Compare Federico, supra note 121, at 183 (the requirement for invention "is an unmeasurable quantity having different meanings for different persons"), with id. at 184 ("The problem of what is obvious and hence unpatentable is still of necessity one of judgment."). 
case law interpreting this new standard correctly has provided an objective and practicable framework tied to third-party investments. ${ }^{159}$

The analysis for a nonobviousness determination under $\S 103$ begins with the entire body of prior art determined to be available under $\S 102 .{ }^{160}$ But important areas of the prior art are then carved out so they can be excluded from the nonobviousness analysis. ${ }^{161}$ First, only art considered to be analogous may be considered under the nonobviousness analysis. ${ }^{162}$ Under the registration theory, which looks to protect the reasonable investment-backed expectations of third parties, non-analogous art is properly discarded because it is not likely to be the

159 See supra notes 151-153 and accompanying text (discussing role of nonobviousness analysis according to registration theory).

${ }^{160}$ See Federico, supra note 121, at 180:

In form this section is a limitation on section 102 and it should more logically have been made part of section 102 , but it was made a separate section to prevent 102 from becoming too long and involved and because of its importance. The antecedent of the words "the prior art," which here appear in a statute for the first time, lies in the phrase "disclosed or described as set forth in section 102" and hence these words refer to the material specified in section 102 as the basis for comparison.

Id.

161 Although all of the $\S 102$ art is initially available for analysis under $\S 103$, certain types of prior art are excluded. According to the registration theory, these carve outs exist to remove from consideration the prior art for which the inference of possible innocent third-party reliance is not reasonable. See infra notes 162-166 and accompanying text (discussing carve outs).

162 The statute provides that the analysis should look to a hypothetical "person having ordinary skill in the art to which [the claimed] subject matter pertains" and ask whether to that person "the [invention] as a whole would have been obvious" given the "differences between the subject matter sought to be patented and the prior art." 35 U.S.C. $\$ 103$ (2000). This in turn requires that several factual inquiries be made: "the scope and content of the prior art are to be determined; differences between the prior art and the claims at issue are to be ascertained; and the level of ordinary skill in the pertinent art resolved." Graham, 383 U.S. at 17. A person having ordinary skill in the art according to this framework is sometimes called a PHOSITA, thanks to the coining of that term by Soans. Cyril A. Soans, Some Absurd Presumptions in Patent Cases, 10 IDEA 433, 438-39 (1966). The "pertinent art" is selected from among the entire set of prior art identified by $\S 102$ depending upon whether it is analogous or non-analogous. According to the Federal Circuit:

Two criteria have evolved for determining whether prior art is analogous: (1) whether the art is from the same field of endeavor, regardless of the problem addressed, and (2) if the reference is not within the field of the inventor's endeavor, whether the reference still is reasonably pertinent to the particular problem with which the inventor is involved.

In re Clay, 956 F.2d 656, 658-59 (Fed. Cir. 1992) (citations omitted); see also Paulsen, 30 F.3d at 1475 (affirming Patent Office rejection under $\S 103$ because references from the fields of cabinetry and desktop accessories are properly considered to be analogous art to a patent claim directed to a clamshell case for a laptop computer under the second of these two alternative criteria). 
basis for any such reliance. ${ }^{163}$ Importantly, as would be predicted by the registration theory, the distinction between analogous and non-analogous art is viewed as important, not as evidence of what the inventor himself or herself could have known about the art, but rather what was knowable to a hypothetical third party having ordinary skill in the art ("PHOSITA"). ${ }^{164}$ Second, secret prior art that would count only under $\S 102(\mathrm{e})$, (f), and (g) has been statutorily excluded from the nonobviousness analysis if it is owned by the same entity whose patent claim is at issue. ${ }^{165}$ The exclusion of this art also makes sense under the registration theory because no third-party investments will have been made in art that is commonly owned and kept secret. ${ }^{166}$

${ }^{163}$ See supra notes 95-96 and accompanying text (discussing purpose of the prior art rules under the registration theory).

164 See Soans, supra note 162, at 438-39 (coining the term PHOSITA). Indeed, Judge Rich, who co-authored $\S 103$, has portrayed this PHOSITA "as working in his shop with the prior art references - which he is presumed to know-hanging on the walls around him." In re Winslow, 365 F.2d 1017, 1020 (C.C.P.A. 1966) (Rich, J.) (this metaphor is referred to as the "Winslow Tableau"); see also Custom Accessories, Inc. v. Jeffrey-Allan Indus., Inc., 807 F.2d 955, 962 (Fed. Cir. 1986) ("The person of ordinary skill is a hypothetical person who is presumed to be aware of all the pertinent prior art.”); Int'l Cellucotton Prods. Co. v. Sterilek Co., 94 F.2d 10, 13 (2d Cir. 1938) (Hand, J.) ("[W]e must suppose the inventor to be endowed, as in fact no inventor ever is endowed; we are to impute to him knowledge of all that is not only in his immediate field, but in all fields nearly akin to that field."). Judge Rich improved upon the Winslow Tableau in In re Antle:

In Winslow we said that the principal secondary reference was "in the very same art" as appellant's invention and characterized all the references as "very pertinent art." The language relied on by the solicitor, quoted above, therefore, does not apply in cases where the very point in issue is whether one of ordinary skill in the art would have selected, without the advantage of hindsight and knowledge of the applicant's disclosure, the particular references which the examiner applied. As we also said in Winslow, "Section 103 requires us to presume full knowledge by the inventor of the prior art in the field of his endeavor" (emphasis, except of "prior," added), but it does not require us to presume full knowledge by the inventor of prior art outside the field of his endeavor, i.e., of "non-analogous" art. In that respect, it only requires us to presume that the inventor would have that ability to select and utilize knowledge from other arts reasonably pertinent to his particular problem which would be expected of a man of ordinary skill in the art to which the subject matter pertains.

444 F.2d 1168, 1171-72 (C.C.P.A. 1971).

165 See 35 U.S.C. $\S 103(\mathrm{c})$ (providing carve outs). The carve outs for $\S 102(\mathrm{f})$ and (g) were added in 1984 to reverse the holding in In re Bass, 474 F.2d 1276, 1288-91 (Fed. Cir. 1973). See Patent Law Amendments Act of 1984, Pub. L. No. 98-622, § 103, 98 Stat. 3383, 3384 (1984). The carve out for $\S 102(\mathrm{e})$ was added in 1999 through $\S 4807$ of the American Inventors Protection Act of 1999. American Inventors Protection Act of 1999, Pub. L. No. 106-113, § 4807, 113 Stat. 1501A-552, 1501A-591 (1999). For a discussion of the history of these carve outs, see Chisum et al., supra note 6 , at 575-78.

${ }^{166}$ No carve out is needed for the novelty analysis because the co-owner can keep the information sufficiently secret before the later claim that the reference will not trigger any of the subsections of $\S 102$, except perhaps $\S 102(f)$. See 35 U.S.C. $\S 102$. For this subsection, 
The content of the remaining prior art as a whole must then be surveyed to determine whether it may have reasonably triggered investment-backed expectations in achieving the subject matter of the patent claim in issue. ${ }^{167}$ Such investments are most likely to have existed only when there can be found among these many remaining pieces of art each and every element of the claimed subject matter along with sufficient teaching, motivation, or suggestion for the pieces that contain those elements to be combined such that there would be a reasonable expectation of success in establishing the claimed subject matter when they are combined. ${ }^{168}$ The practical operation of this analysis can be seen through the use of the schematic claim chart in Table 2, below.

derivation, the co-owner can seek a claim by naming the first inventor, whose activity is coowned. If the earlier reference does not disclose enough to invalidate under a novelty analysis then it would not have been possible for the subject matter to have been claimed at the time of the earlier reference, and the only opportunity to claim the subject matter is at the later time. The exclusion of the prior art from a nonobviousness analysis at that later time helps ensure the possibility of it being covered by a claim. Because the subject matter is co-owned with the prior art and is not otherwise available under any of the other subsections of $\S 102$, it also is not the target of third-party investment.

${ }^{167}$ See supra note 115 and accompanying text (discussing the goal of the nonobviousness requirement according to the registration theory).

${ }^{168}$ According to the Federal Circuit:

The consistent criterion for determination of obviousness is whether the prior art would have suggested to one of ordinary skill in the art that this process should be carried out and would have a reasonable likelihood of success, viewed in the light of the prior art. Both the suggestion and the expectation of success must be founded in the prior art, not in the applicant's disclosure.

In re Dow Chem. Co., 837 F.2d 469, 473 (Fed. Cir. 1988) (citations omitted); see also Chisum et al., supra note 6, at 584-97 (discussing contours of this analysis in practice and collecting sources). 


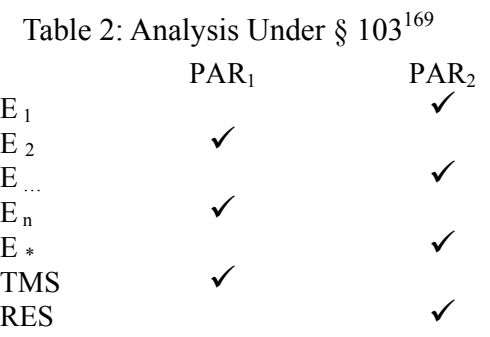

Like Table 1, Table 2 compares the elements of a stylized claim against the prior art, but this time for a determination of nonobviousness under $\S 103 .{ }^{170}$ Invalidity under this rule of nonobviousness also requires the presence in the prior art reference, either expressly or under principles of inherency, of each and every element of the claim, plus enablement. But, unlike the analysis under $\S 102$, the analysis under $\S 103$ allows the elements to be spread among two or more individual pieces of prior art, as long as some additional facts are present: teaching, motivation, or suggestion to combine those references to obtain the subject matter of the claim as a whole ("TMS"), plus a reasonable expectation of success in achieving the claimed subject matter upon the combination ("RES"). ${ }^{171}$ When

${ }^{169}$ As in Table $1, \mathrm{E}_{1}$ through $\mathrm{E}_{\mathrm{n}}$ represent the elements of the claim arbitrarily assigned numbers 1 through $n$; and $E_{*}$ represents enablement of the entire claim. See supra note 146 and accompanying text. In this table, PAR1 and PAR2 each represent any single prior art reference, such as a journal article, sample product, student thesis, etc. The key to the analysis under $\S 103$ is that it permits the looking to more than one reference in the prior art to find all the elements of the claim plus enablement but only if in those references there can also be found (1) a teaching, motivation, or suggestion (TMS in the table) for those references to be combined to form the claimed subject matter as well as (2) a reasonable expectation of success (RES in the table) that the claimed subject matter will result when the references are so combined.

The apparent crispness of this framework may be somewhat illusory for several reasons. First, as with Table 1, there is some uncertainty regarding claim construction. See supra note 147 (discussing uncertainty about the law of claim construction and its application in any given case). Second, as discussed, supra note 162 , the determination of obviousness is to be done from the perspective of a PHOSITA, and the case law leaves some substantial uncertainty as to how this hypothetical person is to be conceptualized. The Federal Circuit has provided a number of factors to consider when determining the characteristics of the PHOSITA:

Factors that may be considered in determining level of ordinary skill in the art include: (1) the educational level of the inventor; (2) type of problems encountered in the art; (3) prior art solutions to those problems; (4) rapidity with which innovations are made; (5) sophistication of the technology; and (6) educational level of the workers in the field.

Envtl. Designs, Ltd. v. Union Oil Co., 713 F.2d 693, 696 (Fed. Cir. 1983); see also Chisum et al., supra note 6, at 597-600 (discussing the case law relating to the determination of the PHOSITA).

${ }^{170}$ See supra note 147 (discussing the validity and patentability analyses).

${ }^{171}$ For a discussion of the case law leading up to this composite test, see supra notes $162-168$ 
mapped onto this table, this means that a proper holding of invalidity or unpatentability under $\S 103$ will only lie if a check mark can be found as a matter of fact for every row and at least some tie can be made across all columns using the TMS and RES that must be found in at least one of the rows. ${ }^{172}$

Unfortunately, the appropriateness of the nonobviousness requirement is not entirely clear under the registration theory. To the extent that the analysis operates as crisply as suggested by Table 2, it makes sense as a reasonably inexpensive way to protect against verifiable investments that may have been made towards a technology. ${ }^{173}$ The practice may deviate some from this framework, however, when requiring that in every case some weight be attributed to the so-called secondary considerations of nonobviousness: chiefly, commercial success and long-felt need and failure of others. ${ }^{174}$ Long-felt need and failure by others may not represent a deviation and may instead fit well within the registration theory's framework as outlined in Table 2 because they may be

172 The nonobviousness analysis is presently pertinent when determining patentability before the Patent Office and when determining validity in litigation, but under a soft-look system would only be relevant in litigation. See supra note 147.

${ }^{173}$ See supra notes 151-153 (discussing role of nonobviousness under registration theory).

174 As the Court in Graham stated when describing these secondary considerations and their purpose:

\begin{abstract}
Such secondary considerations as commercial success, long felt but unsolved needs, failure of others, etc., might be utilized to give light to the circumstances surrounding the origin of the subject matter sought to be patented. As indicia of obviousness or nonobviousness, these inquiries may have relevancy.... .

$\ldots$

... These legal inferences or subtests do focus attention on economic and motivational rather than technical issues and are, therefore, more susceptible of judicial treatment than are the highly technical facts often present in patent litigation. Such inquires may lend a helping hand to the judiciary which, as Mr. Justice Frankfurter observed, is most ill-fitted to discharge the technological duties cast upon it by patent legislation. They may also serve to "guard against slipping into use of hindsight," and to resist the temptation to read into the prior art the teachings of the invention in issue.
\end{abstract}

383 U.S. at 17-18, 35-36 (citations omitted). It is important to realize that even this initial Supreme Court statement of the secondary considerations raises the specter of endeavoring to judge the technological merit of the record rather than its factual content, as the registration theory would require. That is, under the registration theory, the framework is a factual one that anyone well skilled in trial and appellate practice can use, whereas the Court seems to be suggesting a deeper foray into the technological merit by speaking of "technological duties."

The Federal Circuit has gone further than the Supreme Court in Graham by requiring: "evidence rising out of the so-called 'secondary considerations' must always when present be considered en route to a determination of obviousness." Stratoflex, 713 F.2d at 1538-39; see also Chisum et al., supra note 6, at 601-12 (discussing the case law and commentary on the secondary considerations and collecting sources). 
probative evidence of a lack of TMS and RES, in which case the art may fairly be said to "teach away" from the failed approaches. ${ }^{175}$

In contrast, commercial success may deviate materially from the framework of the registration theory, although for reasons different than identified in the literature. ${ }^{176}$ Exemplifying the literature critical of the commercial success factor, Robert Merges urges that the system will operate better when "focus returns to the invention's technical merits" because we should question "the spurious inferential connection between success and significant technical advance." ${ }^{177}$ In his work on the prospect theory, Kitch takes a different view of commercial success arguing that this factor matters under the prospect theory because it shows that the patent has become "the foundation for a series of now valuable contract rights." 178 On first blush it may appear that the commercialization theory would view commercial success the same way, for similar reasons. That is, commercial success might be seen as relevant not because it says something about how hard it was to make the invention, but only because it says something about how commercially relevant the subject matter has become. ${ }^{179}$

Although the commercial success consideration may seem to map on to the incentive to commercialize discussed earlier, it is not clear that this factor

${ }^{175}$ See supra note 171 and accompanying text (discussing TMS and RES); see also In re Gurley, 27 F.3d 551, 553 (Fed. Cir. 1994):

\begin{abstract}
A reference may be said to teach away when a person of ordinary skill, upon reading the reference, would be discouraged from following the path set out in the reference, or would be led in a direction divergent from the path that was taken by the applicant. The degree of teaching away will of course depend on the particular facts; in general, a reference will teach away if it suggests that the line of development flowing from the reference's disclosure is unlikely to be productive of the result sought by the applicant.
\end{abstract}

Id.

${ }^{176}$ In his work pre-dating the prospect theory, Kitch pointed out that commercial success may be a poor indicator of the nonobviousness of an invention because it relies upon too long of a chain of doubtful inferences between the original state of the art and the eventual success. Edmund Kitch, Graham v. John Deere Co.: New Standards for Patents, 1966 Sup. Ct. Rev. 293, 331-33. Commercial success, however, may operate as a good proxy for what was not being done by others to the extent it can be determined that its primary cause is the invention itself, as opposed to other factors such as marketing or happenstance. One problem with making such determinations is that they easily can be influenced by reward theory and thereby become as indeterminate as the reward theory.

${ }^{177}$ Robert P. Merges, Commercial Success and Patent Standards: Economic Perspectives on Innovation, 76 Calif. L. Rev. 803, 838-42 (1988) (citing Kitch, supra note 176, at 330-35).

${ }^{178}$ Kitch, supra note 30, at 282-83.

179 See Kieff, supra note 11, at 707-10 (discussing the commercialization theory's focus on providing incentives for commercialization). 
should be considered if minimizing social cost is the goal. ${ }^{180}$ With the benefit of the registration and commercialization theories combined, commercial success may turn out to be properly ignored as a potential factor of nonobviousness because the factor places too much focus on the merits of the invention, which leads to it not being workable, and not enough focus on the investment-backed expectations by third parties, which is what matters under these theories. ${ }^{181}$ Therefore, in the final analysis, it may not be advisable to abandon the $\S 103$ requirement of nonobviousness in its entirety because most of the nonobviousness framework is shown both to work well according to the registration theory and be well explained by the registration theory. ${ }^{182}$

\section{First-to-Invent}

The patent system's rules governing priority contests between two or more claimants to a patent right protect investment by awarding the patent to the one who was first to invent, not first to file. ${ }^{183}$ As recognized by the commercialization theory, a shift to a first-to-file system may lead to an increased likelihood that neither party in a priority dispute will remain with a valid patent because the increased incentive to file early that may operate to make one party a

${ }^{180}$ See supra notes 85-86 and accompanying text (discussing registration theory's goals of minimizing social cost).

181 See supra notes 27, 81, 106-107 and accompanying text (discussing problems with focus on the merits of the inventions); see also supra notes 93-103 and accompanying text (discussing importance of investment-backed expectations by third parties). In cases where enough time has gone by for there to be evidence of commercial success, there is usually an infringer or two and then the court is left trying to determine whether to decide in favor of the coordination benefits of patents or in favor of protecting the investments of the infringers. In a single-cycle game it may be easy to decide in favor of protecting the infringer's investment. But in a multi-cycle game such a rule would provide incentives to infringe too much and in an uncoordinated fashion and so instead the coordination benefits dominate and evidence of commercial success, or lack thereof, should be ignored, not required.

182 Only to the extent the secondary factors so soften the crispness of the framework modeled in Table 2 that the net benefits of the entire nonobviousness standard fade should it then be abandoned in its entirety. See supra note 46 (suggesting that the registration theory may not require the nonobviousness standard and noting that Kitch, supra note 30, may not be to the contrary). This conclusion, although admittedly not this reasoning, accords with the views of at least one framer of the 1952 Patent Act who described nonobviousness as "the heart of the patent system and the justification of patent grants." Rich, Laying the Ghost, supra note 157, at 1:501.

${ }^{183}$ Whereas priority under a first-to-file system is awarded to the application that is filed first regardless of priority of invention, under a first-to-invent system like the present patent system, priority is awarded to the first inventor. See Kieff, supra note 11, at 749-50 (discussing differences between these two types of priority regimes and collecting sources). 
winner on priority might also have caused that party to file an application with inadequate disclosure. ${ }^{184}$

In contrast, under a first-to-invent system there is less of an incentive to rush to file because priority is not determined by filing and, as a result, there is a lower likelihood that the winner on priority will be left with a patent that fails to meet the disclosure requirements. ${ }^{185}$ The first-to-invent system thereby at least protects the investments of one of the claimants. ${ }^{186}$ In addition, first-to-file may

${ }^{184}$ As explained by the commercialization theory when discussing incentive to file early and its interaction with the disclosure requirements:

\begin{abstract}
A hastily filed application is more likely to be found invalid for nonenablement or lack of written description under recent Federal Circuit case law. See Amgen Inc. v. Chugai Pharm. Co. 927 F.2d 1200, 1213-18 (Fed. Cir. 1991) (applying the statutory requirement that the text of the patent application as filed contain sufficient disclosure to enable one in the art to make and use whatever is covered by patent claims as eventually issued and applying separate written description requirement to claims in the field of biotechnology); Vas-Cath Inc. v. Mahurkur, 935 F.2d 1555, 1563-67 (Fed. Cir. 1991) (holding that the statute also requires the text of the patent application as filed to satisfy the separate and distinct written description requirement so as to reasonably convey to those in the art exactly what is covered by the patent claims as eventually issued); Amgen v. Chugai, 927 F.2d 1200, 1213-18 (applying separate written description requirement to claims in the field of biotechnology); Fiers v. Revel, 984 F.2d 1164, 1170-71 (Fed. Cir. 1993) (solidifying the court's position on a separate written description requirement); Regents of the Univ. of Cal. v. Eli Lilly \& Co., 119 F.3d 1559, 1566-69 (Fed. Cir. 1997) (further solidifying the court's position on a separate written description requirement); Lockwood v. Am. Airlines, Inc., 107 F.3d 1565, 1572 (Fed. Cir. 1997) (applying the same written description requirement to the field of computer software); Gentry Gallery, Inc. v. Berkline Corp., 134 F.3d 1437, 1479-80 (Fed. Cir. 1998) (indicating that the written description requirement is not limited to complex technologies but applies equally to simple technologies, like sofa recliners) .... .
\end{abstract}

Kieff, supra note 11, at 750 n.239; see also S. Leslie Misrock \& Stephen S. Rabinowitz, Side Bar: The Inventor's Gamble: Written Description and Prophetic Claiming of Biotechnology Inventions, in Principles of Patent Law, supra note 6, at 319, 319-22 (discussing the application of the separate written description requirement to claims in the field of biotechnology).

${ }^{185}$ The reasoning here is similar to that for the one-year grace period. See supra note 140 and accompanying text (discussing the importance of the grace period to allow time to file a properly drafted application when measured under the disclosure requirements of $\S 112$ ). For more on the disclosure requirements, see infra Part III.B.

186 The investments of the one who wins the priority dispute are protected. This thereby provides for some commercialization benefit, which is important under the commercialization theory, and some protection of investment-backed expectations on the part of at least one of the parties, which is important under the registration theory. Furthermore, it is generally agreed that under the present system most interference proceedings are won by the first to file anyway. See Edwards v. Strazzabosco, 58 U.S.P.Q.2d (BNA) 1836, 1840 (Board of Patent Appeals and Interferences 2001) (approximate 75\% success rate for the first to file); Charles R.B. Macedo, First-to-File: Is American Adoption of the International Standard in Patent Law Worth the Price?, 18 Am. Intell. Prop. L. Ass'n Q.J. 193, 217 (1990) (same); Gerald J. Mossinghoff, The U.S. Firstto-Invent System Has Provided No Advantage to Small Entities, 84 J. Pat. \& Trademark Off. Soc'y 425, 427 (2002) (between 1983 and 2000, the first to file won 1917 of the 2858 interference cases). But see Charles L. Gholz, A Critique of Recent Opinions in Patent Interferences, 84 J. Pat. 
lead to a winner-take-all mindset for those seeking patents. This, in turn, may cause a reduction in the beneficial inducing power of the reward because each potential claimant may find the possibility of winning the race to be too low. Alternatively, it may cause the harmful, rent-dissipating power to increase as the increase in uncertainty causes even more individuals to gamble on winning the race. $^{187}$

A first-to-invent regime does increase litigation frequency by bringing priority disputes to available contests, but this is beneficial because such disputes can also reach issues of validity. ${ }^{188}$ The costs of determining validity in such a proceeding are likely to be less than in a hard-look examination because the opponent in such a priority dispute is like the alleged infringer in litigation in its ability to more cheaply obtain and evaluate the information needed to determine validity. ${ }^{189}$ The registration theory thereby explains the persistence of the first-toinvent aspect of the present patent system despite harmonization efforts to have the United States match the rest of the world, which uses first-to-file. ${ }^{190}$

\section{Prior Foreign Use}

Like the rules governing novelty generally, the rules about prior foreign use make sense under the registration theory as tools for protecting verifiable investment-backed expectations. ${ }^{191}$ For most of the past century, prior use that was outside of this country would not count for purposes of either staking a claim to priority for purposes of obtaining patent rights in a priority contest or defeating

\& Trademark Off. Soc'y 163, 181 (2002) (suggesting that the U.S. Patent and Trademark Office ("PTO") data reports that the first to file has recently been winning in only $52.5 \%$ of the cases).

187 See Kieff supra note 11, at 711 (discussing Grady \& Alexander, supra note 31, and the problem of rent-seeking and rent-dissipating effects in patent law).

${ }^{188}$ See Charles L. Gholz, Side Bar: Interferences, in Principles of Patent Law, supra note 6, at 511-13 (describing the interference process and its ability to reach issues of validity).

189 The parties to the priority dispute either have the information relating to the prior art themselves because their own work is being used as prior art against each other or they at least have the same if not greater incentives to find that information as does an ordinary defendant in a litigation who is serving the screening function identified by the commercialization theory. See supra notes 5964 and accompanying text (discussing the screening function).

190 See Kieff supra note 11, at 748-50 (discussing harmonization efforts in relation to first-to-file and first-to-invent).

191 See supra note 112 and accompanying text (discussing registration theory on prior art rules and the goal of protecting investment-backed expectations based on objective verifiable evidence). 
patent rights in a challenge to validity. ${ }^{192}$ But since 1994, uses that occur in countries that are members of the North American Free Trade Agreement ("NAFTA") or the World Trade Organization ("WTO") will be available when seeking to obtain a patent in a priority dispute against another claimant-as a sword - but not when seeking to defeat a patent owned by another-as a shield. ${ }^{193}$

By making prior foreign use that occurs within a country with whom we are a trading partner under either of these treaties available to support a claim to a patent, these revisions protect those investment-backed expectations made abroad that are sufficiently serious to have led to the filing of a patent application. ${ }^{194}$ By leaving all other foreign prior use unavailable to defeat a patent, these revisions protect the investments of the one who filed the patent application and disregard those of others whose use is not corroborated by a printed publication. ${ }^{195}$ The registration theory's focus on verifiable evidence of potential investment-backed expectations thereby explains what may otherwise appear to be an intricate effort to favor domestic interests.

\section{B. The Disclosure Rules Help Coordinate}

Under the registration theory, the $\S 112^{196}$ disclosure requirements decrease social costs by serving to give clear notice about the property right, and to decrease the chance of duplicative efforts towards the same invention. ${ }^{197}$ The

192 This is in contrast with the impact of prior use as discussed supra notes 130-132 and accompanying text (discussing rules relating to prior use).

193 See 35 U.S.C. $\S \S 102(\mathrm{~g}), 104$ (2000) (as amended by Uruguay Round Agreements Act, Pub. L. No. 103-465, § 531(a), 108 Stat. 4809, 4982-83 (1994); North American Free Trade Agreement Implementation Act, Pub. L. No. 103-182, § 331, 107 Stat. 2057, $2113-14$ (1993)). For more on the operation of these new provisions, see Chisum et al., supra note 6, at 489-91 (discussing legislative changes and explaining their practical impact).

${ }^{194}$ See supra note 112 (discussing registration theory on prior art rules and the goal of protecting investment-backed expectations based on objective verifiable evidence).

195 See supra notes 127-128 and accompanying text (printed publications anywhere in the world may be available as prior art because they are verifiable).

19635 U.S.C. $\$ 112$ paras. 1-2 (setting forth the disclosure requirements of patent law: (1) written description; (2) enablement; (3) best mode; and (4) definiteness, which is also stated as the requirement that the claims "particularly point[] out and distinctly claim[]"). The requirements of enablement, written description, and best mode are each judged by comparing the claims as issued to the application as filed. See id. para. 1 (requirements of the specification as filed); id. $\S 132$ (prohibition against adding new matter). For a discussion of the operation of the disclosure requirements, see Chisum et al., supra note 6, at 161-322.

${ }^{197}$ This signaling function is recognized by Kitch in his discussion of the prospect theory. Kitch, supra note 30, at 287 ("The purpose of the description in the patent is not to disclose the 
U.S. Court of Appeals for the Federal Circuit's strong reading of the written description requirement to put the public on clear notice of what will infringe and what will not makes sense because the patentee, as the drafter, is the least-cost avoider of such ambiguities. ${ }^{198}$ This legal development was controversial to be sure; yet it marks an important weapon in the system's arsenal for fighting social cost. Pro-patent arguments against this development because it leads to the invalidation of particular patents should be ignored because this requirement helps to minimize the social cost of the system. ${ }^{199}$ Anti-patent arguments focused on particular patents - such as those on gene fragments - should also be ignored. Such patents are much less likely to cause the pernicious clogging of downstream innovation than feared. In addition, transaction costs may not be as big of an obstacle as they may seem, ${ }^{200}$ because under this case law many such downstream activities would not infringe most such valid claims. ${ }^{201}$

commercially relevant technology, but to provide a context in which the legal limits of the claim acquire meaning.").

198 See supra note 184 (discussing disclosure rules and their impact on patentees' decisions to file more complete disclosures at time of filing).

${ }^{199}$ Because the applicant's patent attorney drafts the disclosure for the patent application before filing, she is the least-cost avoider of litigation on compliance with the disclosure requirements as long as the legal standards for these requirements are clear and attainable.

${ }^{200}$ See generally Eisenberg, Experimental Use, supra note 6 (exploring an experimental use exemption from patent infringement as a device for alleviating potential negative impact of patent rights on scientific norms in the field of basic biological research); Eisenberg, Norms of Science, supra note 6 (exploring potential negative impact of patent rights on scientific norms in the field of basic biological research); Eisenberg, Public Research, supra note 6 (offering preliminary observations about the empirical record of the use of patents in the field of basic biological research and recommending a retreat from present government policies of promoting patents in that field); Heller \& Eisenberg, supra note 6 (arguing that patents can deter innovation in the field of basic biological research); Rai, supra note 6 (suggesting that patents on multiple gene fragments, such as ESTs, could block the use of a larger DNA sequence of which they are a part).

${ }^{201}$ Kieff, supra note 6, at 699-700 (showing why a patent claim directed to a gene fragment like an EST cannot be construed to cover a larger DNA sequence, such as a substantial portion of an entire gene, and citing Kieff, supra note 11, at 721-22 (noting that if the patentee attempts to argue that the claim to the smaller fragment covers the fragment within the environment of the larger DNA, then the claim is likely to be held invalid over the prior art or for lack of adequate disclosure because to be valid, the claimed subject matter must be new and nonobvious, and the patent application must disclose the metes and bounds of the claimed subject matter with physical and chemical detail as well as how to make and use it, and alternatively pointing out that because ESTs exist in nature in the company of the other DNA of the genome, a typical EST claim must be limited in order to overcome this prior art to a version of the EST in some specific environment other than its natural one, such as isolated from all other DNA or inserted into an artificially engineered piece of DNA, and the details of the degree of isolation or of the engineered piece of DNA must also be provided so as to satisfy the disclosure requirements)). Ironically, many of the arguments that see a large anticommons problem with 
Although not strictly speaking a requirement about the content of a patent application, the new statutory requirement for publication of applications eighteen months after filing is properly considered here. ${ }^{202}$ This is because it can operate similarly to the disclosure requirements in improving the important signaling function patents play in controlling the potential rent-seeking, and therefore rentdissipating, behavior of those others who also might be working towards the same invention as claimed in the patent. ${ }^{203}$ Indeed, the registration model explored in this Article would go a great deal further towards disseminating information about patent applications by posting them on the World Wide Web for free as soon after filing as administratively practicable. ${ }^{204}$

\section{Summary: The Name of the Game is the Claim}

The registration theory's view that the patent system can and should operate to minimize social costs is confirmed by recent and important empirical work by John Allison and Lemley, which shows that by almost any measure patents are becoming what they call "more complex" over time. ${ }^{205}$ The increase in the number of prior art references cited and the length of prosecution before the Patent Office, which Allison and Lemley identify and then use as proxies for complexity, can be seen as evidence that issued patents are getting better scrutiny

patents on things like ESTs also criticize these aspects of the Federal Circuit's approach to the written description requirement; yet the latter ameliorates the former.

202 American Inventors Protection Act of 1999, Pub. L. No. 106-113, § 4502, 113 Stat. 1501A-552, 1501A-561 (1999) (codified as amended at 35 U.S.C. $§ 122$ (2000)) (eighteen month publication of applications).

203 Thus, the eighteen-month publication provision of patent law is one for which the prospect and rent dissipation theories discussed supra Part I also have good explanatory power.

${ }^{204}$ For a discussion of the registration model, see supra Part II. Although the registration theory suggests adoption of the registration model and immediate publication, the registration theory may not be quite as supportive of such pre-issuance publication under an examination system like the present one because it will have to reach compromises that are undoubtedly fair from a systemic perspective but that will yield a variety of incentives for strategic behavior, such as the incentive by competitors to, before grant of the patent, use the publication to teach them how to engage in as much otherwise infringing activity as possible, and the incentives to achieve a stronger bargaining position against a competitor using the leverage of its investments based on a public use up to just under thirty-six months before publication of the application (based on the combined one-year grace period and eighteen-month publication windows). For a discussion of the legislative compromises reached under the eighteen-month publication provisions of the current system, see Chisum et al., supra note 6, at 116-22.

205 John R. Allison \& Mark A. Lemley, The Growing Complexity of the United States Patent System, 82 B.U. L. Rev. 77 passim (2002) (providing empirical evidence on complexity of patents). 
without moving towards a hard-look system. ${ }^{206}$ Furthermore, the increase in variation among patents identified by the Allison and Lemley article can be seen as evidence of increased selectivity in deciding which patents get increased scrutiny. ${ }^{207}$

The combination of these two effects provides some evidence that it is patentees themselves who are acting rationally to choose to increase scrutiny on only those patents they believe to be most important. ${ }^{208}$ If so, then they are acting in a way that both internalizes and mitigates social cost. ${ }^{209}$

Patentees are motivated to rationally choose to behave this way because they face a complex gamble when selecting claim scope. ${ }^{210}$ The requirements for

${ }^{206}$ Cf., e.g., Josh Lerner, Where Does State Street Lead? A First Look at Finance Patents, 1971-2000, at 28 (Nat'l Bureau of Econ. Research, Working Paper No. 7918, 2000), at http://www.nber.org/papers/w7918 (suggesting that poor patent quality of some early business method patents may be due to their relatively anemic citation of prior art, which is one of the complexity parameters explored by Allison and Lemley, supra note 205).

${ }^{207}$ Patent applicants and their patent attorneys draft the patent disclosure and claims. The Patent Office can reject or allow the claims but otherwise has only limited input to the content. For an overview of the process of arguing to the Patent Office for the right to a patent, which is called "patent prosecution," see Chisum et al., supra note 6, at 91-128. The increase in variation seen by Allison and Lemley is therefore evidence that some patentees are choosing to seek patents that are less likely to withstand challenge in court, and others are seeking patents that are more likely to withstand such challenge.

208 That is, this may be evidence of a type of self-screening by the patentees themselves based on what challenges to validity they anticipate their competitors might mount. See supra notes 59-64 (discussing the screening function). Importantly, to make these determinations effectively, the patentees themselves often have to seek out the very information relating to validity that, in the first instance, is in the hands of third parties and would cost an opponent of the patentee substantial money to seek out and bring to bear later to support arguments over validity in civil litigation. Patentees are thereby internalizing those social costs when they get this information and the litigation conduct reforms discussed infra Part IV.E would provide added incentives for patentees to put this information to proper use. For more on self-screening by patentees, see generally John R. Allison \& Emerson H. Tiller, The Business Method Patent Myth, 18 Berkeley Tech. L.J. (forthcoming November 2003) (referring to this issue as the "self-selected value theory"), available at http://papers.ssrn.com/abstract=421980; John R. Allison et al., Valuable Patents, 92 Geo. L.J. (forthcoming 2004), available at $\mathrm{http}: / /$ papers.ssrn.com/abstract $=426020$.

${ }^{209}$ Those patents that are getting better treatment up front by the applicants are less likely to cause the pernicious impact associated with the one-click patent discussed supra notes 1-4 and accompanying text, which is caused by any issued patent that is legally presumed valid because it issued yet nevertheless quite likely to be held invalid in court in practice. See supra Part II (comparing the advantages of the registration model over the present examination practice).

${ }^{210}$ Many of the important decisions facing a patentee must be made ex ante before filing the application for several reasons. First, the disclosure requirements compare the claims as issued against the application as filed. See supra Part III.B. Second, the statutory bar aspects of the prior art requirements measure the claims as issued against the state of the art at filing. See supra Part 
patentability discussed above operate in concert to force a form of self-discipline on patent scope that mitigates the complex economic concerns explored by Merges and Richard Nelson. ${ }^{211}$ As Judge Giles S. Rich often said about patents, "the name of the game is the claim ... [and] the function of claims is to enable everyone to know, without going through a lawsuit, what infringes the patent and what does not." 212 According to Judge Rich, claims present a fundamental dilemma for every patentee because "the stronger a patent the weaker it is and the weaker a patent the stronger it is. $" 213$ By this he meant that a broad patent claim is strong on offense because it covers more and, therefore, is more likely to be infringed, but it also is weak on defense because it may cover something in the prior art or fail to be supported by a sufficiently detailed disclosure in the rest of the patent, and, therefore, is more likely to be invalid. In contrast, a narrow claim is weak on offense, because it covers less and, therefore, is less likely to be infringed, but it also is strong on defense because it is likely both to avoid the prior art and to be supported by a sufficiently detailed disclosure, and, therefore, also is less likely to be invalid. ${ }^{214}$

To be sure, a patentee's offensive drive is strong, but it is also strongly undercut by the defensive drive via the linkage through claim breadth. ${ }^{215}$ This is because the costs of preparing a patent with claims of meaningful scope are substantial, whereas an adjudication of invalidity destroys all private value of the patent. $^{216}$ The patentee's drafting decisions before filing must take into

III.A.1. Therefore, patentees must always balance the time needed to write a sufficient disclosure against the chance this time will allow for the creation of so-called "intervening art," because it came into existence between the date of invention and the date of filing.

${ }^{211}$ Merges \& Nelson, supra note 91, at 845 (exploring economic implications of varying patent scope).

212 See, e.g., Giles S. Rich, The Extent of the Protection and Interpretation of ClaimsAmerican Perspectives, 21 Int'l Rev. Indus. Prop. \& Copyright L. 497, 499, 501 (1990), quoted in Hilton Davis Chem. Co. v. Warner-Jenkinson Co., 62 F.3d 1512, 1539 (1995) (Plager, J., dissenting, joined by Archer, C.J., and Rich \& Lourie, JJ.), rev'd, 520 U.S. 17 (1997). Although Judge Rich made these remarks in a discussion about the benefits of the present examination system, they are even more germane to the model registration system.

${ }^{213}$ See Giles S. Rich, The Proposed Patent Legislation: Some Comments, 35 Geo. Wash. L. Rev. 641, 644 (1967) (emphasis omitted) (responding to proposed legislation S. 1042, 90th Cong. (1967) and H.R. 5924, 90th Cong. (1967) and President's Comm'n on the Patent Sys., “To Promote the Progress of . . Useful Arts" in an Age of Exploding Technology (1966)).

${ }^{214} I d$. (explaining patentee's dilemma, or "riddle").

215 See supra notes 212-214 (discussing the linkage).

${ }^{216}$ Although the filing fees paid to the Patent Office are relatively modest, the costs of attorney and client time to draft a disclosure that will comply with the patent-obtaining requirements can be well over ten times that amount. As of January 1, 2003, the basic filing fee is 
consideration several factors. First, compliance with the disclosure requirements, when tested in litigation, looks to the disclosure made at filing. ${ }^{217}$ Second, if the patentee amends the application that was originally filed, then the scope the patentee may later be able to capture in an infringement suit through recourse to the doctrine of equivalents ("DOE") may be cabined by the doctrine of prosecution history estoppel, which is triggered by such amendments. ${ }^{218}$ Third, because the best information about validity is most likely to be held by parties other than the patentee, ${ }^{219}$ the patentee experiences substantial incentive either to err on the side of narrowness or to obtain that information so the patent can be drafted around it. ${ }^{220}$ It is this incentive for the patentee to make its own correct determination of validity and scope before filing that helps explain the evidence discussed above from Allison and Lemley that patentees themselves are making decisions that tend to keep their own patent scope "just right" from a social perspective. $^{221}$

This view of what makes scope just right under the registration theory is quite different from those under the reward, prospect, or rent dissipation theories.

$\$ 740$, or $\$ 370$ for what the Patent Office views as a "small entity." 37 C.F.R. $\$ 1.16(a)$ (2003). The attorney's fees for preparing and prosecuting the application are described by Lemley as follows:

\begin{abstract}
Prosecuting patents is expensive. There is some disagreement on precisely how expensive it is, but the general range of costs for prosecuting a patent from start to finish (including application and various filing fees paid to the PTO, and attorney's fees not only to prepare and file the application, but to respond to office actions and continue prosecution through to issuance or abandonment) appears to be $\$ 10,000$ to $\$ 30,000$ per patent. I have chosen a conservative average estimate of $\$ 20,000$ per initial application taken through prosecution. Much of this cost is front-loaded: it covers an attorney's time in meeting with the inventor, writing the application, and writing patent claims, as well as a substantial filing fee to the PTO. Other costs are incurred on a piecemeal basis as prosecution progresses, and include both attorney's fees and PTO fees to file each new piece of paper, up to and including the issuance of the patent itself. These cost averages include both patents that are ultimately issued and patent applications that are ultimately rejected by the PTO without being revived.
\end{abstract}

Lemley, supra note 6, at 1498-99 (footnotes omitted) (collecting sources).

${ }^{217}$ See supra note 196 (discussing the disclosure rules).

${ }^{218}$ See, e.g., Warner-Jenkinson Co. v. Hilton Davis Chem. Co., 520 U.S. 17, 25-34 (1997) (reaffirming the doctrine of prosecution history estoppel as a legal limit on DOE).

${ }^{219}$ See supra Part III.A.1 (discussing the many types of prior art that are in the hands of those other than the patentee).

${ }^{220}$ A patent claim that ends up covering any part of the prior art is invalid. See supra notes 123-124. Under the registration theory, post-issuance procedures available to amend the claims under the present examination system should be avoided to ensure that the patent applicant has the strongest incentive possible to get right the document that is registered and published and on which everyone will rely.

${ }^{221}$ See supra notes 205-207 and accompanying text (discussing the evidence). 
Importantly, scope that is just right under the registration theory is scope that is determined using lowest administrative costs possible to do two things: (1) protect verifiable investment-backed expectations by avoiding patenting of the prior art; and (2) facilitate bargaining over, and avoidance of, the patent by ensuring the application's disclosure and claims combine to leave the patent scope as clear as possible. Patent scope achieved this way does not simply depend upon trivial decisions on the margin to file additional claims of different scope. Rather, each claim can be thought to represent a class of potentially infringing members. Under the patent-obtaining rules, that class must be adequately disclosed and none of its members must have been within the prior art. Under hard-look systems, such claims may have pernicious impact because they may be presumed valid although actually likely to be proven invalid if challenged. Under soft-look systems, especially the registration model, the private benefit an applicant would get from strategic games involving the filing of excessive variation in claims decreases. At the same time, for those claims that happen to have appropriate scope, the public cost decreases and the public benefit increases. Indeed, the patentee's private efforts, at the time of drafting, to achieve the maximum scope allowable under the patent-obtaining rules facilitates later evaluation of the patent's potential validity and infringement by potential transaction partners, competitors, and courts. ${ }^{222}$ Therefore, as suggested by the registration theory, there are a number of essential registration aspects inherent in the present examination system and they help minimize social costs.

\section{Lessons from the Model for the Present Patent System}

The registration model and its accompanying registration theory show that the present patent system, which is based on examination, in fact operates with many registration aspects. ${ }^{223}$ Nevertheless, the registration theory shows how the system could be improved by a number of reforms of varying severity. More specifically, the registration theory elucidates the benefits of a number of reforms relating to statutory subject matter and utility, DOE, deference to the Patent Office, and post-issuance procedures, which could all be adopted without switching to a fully soft-look system like the registration model. ${ }^{224}$ The registration theory also elucidates the benefits of reforms relating to litigation of

222 The reforms discussed infra in Part IV.E help each of these parties use this information, and the information relating to the prior art and infringement.

${ }^{223}$ See supra Part III.

${ }^{224}$ See infra Parts IV.A-D (discussing reforms relating to statutory subject matter and utility, DOE, deference to the Patent Office, and post-issuance procedures). 
patents and the presumption of validity that essentially would have the effect of switching to a soft-look system like the registration model. ${ }^{225}$

\section{A. Reforms for Subject Matter and Utility}

The $\S 101^{226}$ requirements of utility and statutory subject matter should be amended to avoid the public choice and administrative costs they have inflicted over the years. ${ }^{227}$ Both of these requirements have been used to invalidate patents

${ }^{225}$ See infra Part IV.E (discussing reforms relating to litigation of patents and the presumption of validity).

22635 U.S.C. $§ 101$ (2000) (statutory subject matter and utility).

${ }^{227}$ A variety of per se exclusions in patent law have been perceived. See, e.g., Diamond v. Diehr, 450 U.S. 175, 187 (1981) ("A claim drawn to subject matter otherwise statutory does not become nonstatutory simply because it uses a mathematical formula, computer program, or digital computer."); Diamond v. Chakrabarty, 447 U.S. 303, 309-18 (1980) (holding living organisms not per se unpatentable); State St. Bank \& Trust Co. v. Signature Fin. Group Inc., 149 F.3d 1368, 1370-77 (Fed. Cir. 1998) (hub-and-spoke mutual fund accounting system is patentable subject matter); In re Alappat, 33 F.3d 1526, 1541-45 (Fed. Cir. 1994) (en banc) (computer system for producing a smooth waveform on a raster display is patentable subject matter).

The central problem with these perceived exclusions is that they did not provide workable distinctions ex ante between what would prospectively be considered the line between the patentable and the unpatentable, leaving decisionmakers to entertain arguments about a special exception in any case from anyone able to fund the attack. See supra note 80 (discussing some public choice problems associated with this type of decision making). These ever-shifting sands prevented some industries, like the computer software business, from gaining sufficient traction to organize themselves into anything but industries characterized by a single large player-for example, Microsoft. See Kieff, supra note 11, at 744 (the inability to obtain meaningful "patent protection for software for such a large and important portion of the industry's life may have contributed to the continued unchallenged dominance of a huge entity like Microsoft"). The result was bleak and remarkably reminiscent of the one described by Dickens:

\footnotetext{
At the Patent Office in Lincoln's Inn, they made 'a draft of the Queens bill', of my invention, and a 'docket of the bill'. I paid five pound, ten, and six, for this. They 'engrossed two copies of the bill; one for the Signet Office, and one for the Privy-Seal Office'. I paid one pound, seven, and six, for this. Stamp duty over and above, three pound. The Engrossing Clerk of the same office engrossed the Queen's bill for signature. I paid him one pound, one. Stamp-duty again, one pound, ten. I was next to take the Queen's bill to the Attorney-General again, and get it signed again. I took it, and paid five pound more. I fetched it away, and took it to the Home Secretary again. He sent it to the Queen again. She signed it again. I paid seven pound thirteen, and six, more, for this. I had been over a month at Thomas Joy's. I was quite wore out, patience and pocket.
}

Charles Dickens, A Poor Man's Tale of a Patent, in Charles Dickens and the 'Poor Man's Tale of a Patent' 15, 18-19, 29 (Jeremy Phillips ed., 1984) (including appendices about the "circumlocution office" described to be "(as everybody knows without being told) the most important Department under Government"). 
or deny patents based on arguments that make no sense when mapped onto the patent system. ${ }^{228}$ They are vestiges of reward theories and are unworkable.

Although $\S 101$ of the statute is generally viewed as setting forth two requirements for patentability-utility and subject matter-the case law ${ }^{229}$ provides some authority for the proposition that this section is either merely prefatory, or designed to rule in what years of case law had tried to rule out. Section 101 provides in its entirety:

$\S 101$. Inventions patentable

Whoever invents or discovers any new and useful process, machine, manufacture, or composition of matter, or any new and useful improvement thereof, may obtain a patent therefor, subject to the conditions and requirements of this title. ${ }^{230}$

During a surprisingly active exchange of cases between the U.S. Supreme Court and the Court of Customs and Patent Appeals ("C.C.P.A.") (the predecessor court to the U.S. Court of Appeals for the Federal Circuit) involving the famous cases of In re Bergy and Diamond v. Chakrabarty, the anatomy of this statute was carefully dissected. ${ }^{231}$ In 1979, the C.C.P.A. in Bergy decided that "in 1952 Congress voiced its intent to consider the novelty of an invention under $\S 102$ where it is first made clear what the statute means by 'new', notwithstanding that this requirement is first named in $\S 101 ., 232$ The same reasoning would support the view that the word "utility" should be considered under the disclosure requirements of $\S 112$, such as "enablement," despite that it is first named in $\S 101$ as well.

If a statutory construction approach is unconvincing, a review of theory may be. The utility requirement should be low because the requirement itself serves no economic purpose. A useless patent will not be infringed. ${ }^{233}$ Moreover, for a patent that lacks utility because of a lack of practical application, at least the information published in the patent teaches something good (and again no one

${ }^{228}$ See, e.g., infra notes 236,240 and accompanying text.

${ }^{229}$ See infra notes $231-232$ and accompanying text.

${ }^{230} 35$ U.S.C. $\S 101$.

${ }^{231}$ Chakrabarty, 447 U.S. at 307-18; Bergy, 596 F.2d 952, 959-64 (C.C.P.A. 1979) (Rich, J.), dismissed as moot, 444 U.S. 1028 (1980) (companion case to Chakrabarty).

${ }^{232} 596$ F.2d at 961.

${ }^{233}$ Kieff, supra note 11, at 721-22 (showing why the utility requirement is itself useless and why lack-of-utility arguments are most generously viewed as non-infringement of a properly construed claim so as to avoid the apparently inconsistent position of a defendant showing the activity to be of sufficient use to have prompted the infringement lawsuit while arguing that they are of no use). 
will infringe). If there is lack of utility due to the inventor getting the science or engineering underlying the alleged invention wrong, then the information published is valuable in teaching others what not to do. Finally, a patent of uncertain commercial utility provides incentives for the patentee to license broadly. ${ }^{234}$

The case law controlled by the 1995 decision of the Federal Circuit in In re Brana has largely adopted this view and today, as a matter of positive law, courts give a great deal of deference to a patent applicant's assertion of utility. ${ }^{235}$ To some extent this case law may be inconsistent with the Supreme Court's 1966 decision in Brenner v. Manson. ${ }^{236}$ Nevertheless, because a utility requirement would not protect any investment-backed expectations and proponents of a strong requirement fail to give any test for utility that is administrable, the registration theory suggests the requirement should simply be abandoned. ${ }^{237}$

The statutory subject matter requirement should also be low-fixed at "anything under the sun made by man" 238 - to avoid both the problems of setting categories of subject matter and the inevitable wasteful costs that would be spent by parties near the margins between categories. ${ }^{239}$ The charge that the law must

${ }^{234} I d$. at 726 (discussing the powerful incentive to license broadly that is caused by risks of commercialization, such as those that would obtain where commercial utility is uncertain).

${ }^{235}$ According to the Federal Circuit, a two-step analysis is required:

[First, the Patent Office or alleged infringer] has the initial burden of challenging a presumptively correct assertion of utility in the disclosure. [Second,] [o]nly after the [challenger] provides evidence showing that one of ordinary skill in the art would reasonably doubt the asserted utility does the burden shift to the applicant to [prove utility].

Brana, 51 F.3d 1560, 1566 (Fed. Cir. 1995) (citations omitted).

${ }^{236}$ See 383 U.S. 519, 535-36 (1966) (holding patent invalid for lack of utility, perhaps because there was no specific commercial use of the products produced by the claimed process, stating "a patent is not a hunting license"); see also Chisum et al., supra note 6, at 707-27 (recognizing the inconsistency and discussing modern treatment).

${ }^{237}$ The prospect, rent dissipation, commercialization, and registration theories would each see the granting of a hunting license to be entirely appropriate either as an effort to coordinate the hunt to avoid the risk of accidental shootings, to avoid racing, or because there are no investmentbacked expectations to protect.

238 Chakrabarty, 447 U.S. at 309 (quoting S. Rep. No. 82-1979, at 5 (1952); H.R. Rep. No. 82-1923, at $6(1952)$ ).

${ }^{239}$ For example, consider that during the prior case law when software was perceived to be unpatentable, applicants would simply claim it "in a box" or "on a disk" by drafting claims to a general purpose computer (a thing) programmed a certain way or a magnetically recordable medium (again a thing) on which a certain message had been recorded. For a detailed discussion of the evolution in this area, see Chisum et al., supra note 6, at 728-828. For more on the problems of per se categories of unpatentable subject matter, see Allison \& Tiller, supra note 208. 
change to accommodate new subject matters for which patents are being sought makes little sense. Among the many legal regimes that might possibly face a charge of not being designed to deal with new technologies, the patent system must have the best defense precisely because it is the one system expressly designed with such unforeseen technologies in mind. ${ }^{240}$ Indeed, technologies that are so foreseeable as to be obvious are not patentable in view of the system's most basic patentability requirement: that the claimed invention not be in the prior art. As a result, we should, at a minimum, avoid adopting the suggestion by some critics that we develop special rules to accommodate particular areas of patentable subject matter where protection is only recently being sought, such as biotechnology, computer software, and finance. We perhaps also should be clearer in holding that the law is firmly settled on this issue by expressly stating that statutory subject matter raises no distinct hurdle to patentability. ${ }^{241}$

\section{B. Reforms for the Doctrine of Equivalents}

An understanding of incentive for individual patentees to get patent scope "just right" ${ }^{242}$ provides some guidance on the ongoing battle over the DOE, which allows a patentee to win an infringement suit against something that is not literally covered by the claims. ${ }^{243}$ Allowing the patentee recourse to this doctrine is bad in that it weakens the important self-disciplining effect described above; eliminating the doctrine would be good in that it would accentuate this incentive. $^{244}$

${ }^{240}$ The majority opinion of the sharply divided Supreme Court embraced this view in Chakrabarty: "This is especially true in the field of patent law. A rule that unanticipated inventions are without protection would conflict with the core concept of the patent law that anticipation undermines patentability." 447 U.S. at 316.

${ }^{241}$ As the Federal Circuit recognized in 1998 in State Street Bank:

The question of whether a claim encompasses statutory subject matter should not focus on which of the four categories of subject matter a claim is directed to-process, machine, manufacture, or composition of matter - but rather on the essential characteristics of the subject matter, in particular, its practical utility. Section 101 specifies that statutory subject matter must also satisfy the other "conditions and requirements" of Title 35, including novelty, nonobviousness, and adequacy of disclosure and notice.

149 F.3d at 1375 (footnote omitted).

242 See supra notes 210-221 and accompanying text.

${ }^{243}$ See, e.g., Warner-Jenkinson, 520 U.S. at 24-41 (discussing the doctrine of equivalents and its limits).

${ }^{244}$ Recent work by Wagner makes a similar argument to justify cabining the reach of DOE. See Wagner, supra note 50, at 244. 
Importantly, this criticism of the DOE is not merely driven by concerns about absolute crispness, or advantages of rules over standards. ${ }^{245}$ Rather, the core argument is a matter of comparative institutional economics.

To understand the intuition of the argument it may help to first consider that the DOE is structurally at odds with the basic approach to claims under the present positive law rules of the patent system, which together yield an approach known as "peripheral claiming" — as distinct from "central claiming" — in which the function of the patent claim is not to set forth the heart of the protected subject matter but rather to set forth its outer bounds. ${ }^{246}$ A determination of infringement under a central claiming approach requires the court to determine the heart of the invention and whether the putative infringement is close enough to that heart to justify a judgment of infringement. A determination under peripheral claiming requires the court to determine only the outer bounds of the claim. Anything within those bounds infringes and anything outside does not. The DOE in the present patent system, even though not provided for in the statute, is an odd exception to the peripheral nature of our present peripheral claiming system precisely because it allows the patentee to capture something outside of the claim. ${ }^{247}$

Although the DOE has some general intuitive attraction because it gives some flexibility, the registration theory shows how the patentee can achieve even greater flexibility in a manner that is not only less costly to the patentee but also to all third parties by simply drafting a better patent disclosure at the outset. Under the disclosure rules of patent law, the patentee at the time of filing can draft a disclosure that will support claims of varying scope. ${ }^{248}$

It may be possible that the information-forcing benefits of a system with no DOE would be outweighed by the added costs it may encourage some patent applicants to incur as a precaution. But, on a per-patent basis, the direct costs to patentees of this drafting effort (largely legal fees) are substantially less than those associated with litigating DOE issues later in court. In addition, the indirect costs of having to decide whether this extra flexibility on scope is worth such direct

${ }^{245}$ For more on the general debate about rules over standards, see supra note 17.

${ }^{246}$ For more on peripheral claiming, see F. Scott Kieff, Perusing Property Rights in DNA, in Perspectives on Properties, supra note 56 at 125, 135. See also supra Part III.C. (discussing claims under the present system).

${ }^{247}$ This may be one reason why the principal drafter of the present system, Judge Rich, joined two of the dissenting opinions in Hilton Davis Chemical Co. v. Warner-Jenkinson Co. that objected to the DOE. 62 F.3d 1512, 1536 (1995) (Plager, J., dissenting, joined by Archer, C.J., and Rich \& Lourie, JJ.), rev'd, 520 U.S. 17 (1997); id. at 1545 (Lourie, J., dissenting, joined by Rich \& Plager, JJ.).

${ }^{248}$ See infra notes 251-258 and accompanying text. 
costs will be cabined to some extent by the small size of the potential gain from avoiding the direct costs themselves. Even if it turned out that putative patentees, on average, do not make at least roughly appropriate decisions about which of their own patents deserve more or less attention at the drafting stage, a significant moral hazard problem certainly would arise if decisions on application of the DOE were understood to turn on this type of error by individual patentees. Moreover, the DOE imposes substantial litigation costs on competitors of the patentee. The general uncertainty arising out of the DOE can also chill business transactions of all sorts, including commercialization efforts by competitors and downstream developers as well as by business partners of even the patentee.

It also may be possible that the information-forcing benefits of a system with no DOE would be outweighed by other costs to the system. One major component of these countervailing costs will be the decreased commercialization benefits to society that would be associated with those inventions protected by patents whose patentees, at the time of filing, elected to spend too little on patent drafting. But once again, a significant moral hazard problem certainly would arise if decisions on application of the DOE were understood to turn on this type of error by individual patentees as well.

Alternatively, as Douglas Lichtman suggests, information forcing may be of no benefit if, at the time of filing, the patentee may not be able to draft an application that could convey appropriate patent scope given the inevitably changing state of technological vocabularies. ${ }^{249}$ But to the extent it suggests that a patentee somehow deserves the broader scope captured by the DOE, this view of what is an appropriate patent scope would seem to be based on a version of a reward theory and would fail to account for the focus on minimizing social cost that is central to positive law rules for patentability-especially the disclosure rules - as elucidated by the registration theory. ${ }^{250}$

In addition, it is not clear whether such concerns about changes in technology actually obtain, as a practical matter, under a peripheral claming system. Under a peripheral claiming approach, each claim can be viewed as a simple logical list in which each word, or element, in the claim is considered a required item in the list. This list of elements can be compared against the allegedly infringing product or process in much the same way it was compared against the prior art in Tables 1 and 2. ${ }^{251}$ Patent infringement occurs when each

249 See, e.g., Douglas Lichtman, Rethinking Prosecution History Estoppel 27-28 (Univ. of Chi., John M. Olin Law \& Econ., Working Paper No. 200, 2003), available at http://ssrn.com/abstract $=455380$.

${ }^{250}$ See supra note 222 and accompanying text (discussing what makes scope just right under the registration theory). See generally supra Part III.

251 See supra notes 146 (describing Table 1) and 169 (describing Table 2) and accompanying text. 
and every element of the claim can be found in the allegedly infringing product or process. ${ }^{252}$ According to such a comparison, the more elements there are, the harder it is to infringe. Instead of trying to determine and then recite in the claim every particular use by potential future infringers, a prudent patentee under such a system tries to determine the general nature of these potential uses and then recites them as a class in the claim. For example, rather than drafting a claim that recites, among other elements, a list of specific expected fastener technologies such as nails, screws, and Velcro ${ }^{\circledR}$, a prudent patentee might recite "a fastener" as a claim element and then elsewhere in the patent provide a careful disclosure of what is meant by this term including a qualitative description and representative examples. $^{253}$

This approach to claiming and drafting deals well with even unknowable future technologies. Put simply, this is the job of a good patent lawyer and one reason why patents are legal documents drafted by lawyers for interpretation by judges and lawyers, not technical documents evaluated by peer review. ${ }^{254}$ The standard for satisfaction of the disclosure rules' written description requirement is merely whether the disclosure as filed conveys to a PHOSITA ${ }^{255}$ that the inventor had possession of the claimed invention at that time; ipsis verbis disclosure is not needed. $^{256}$ As a result, a prudent drafter easily can employ claim elements that are disclosed to be a "genus and its constituent species" (or a class of constituent members) without having to identify in the disclosure every single species (or member), as long as the disclosure provides a clear indication of how to determine membership in the genus (or class), which can be shown through the analogy to a path through a forest marked by certain trees:

It is an old custom in the woods to mark trails by making blaze marks on the trees. It is no help in finding a trail ... to be confronted simply by a large

${ }^{252}$ For a detailed discussion of the law of infringement, see generally Chisum et al., supra note 6 , at 829-73. Also recall the maxim linking the tests for infringement and anticipation. See supra note 124 .

${ }^{253}$ In contrast, under a central claiming system, there can be a premium to reciting in the claim examples of the particular items that are likely to be infringing because, unless expressly mentioned, such items are unlikely to be considered sufficiently central to the claim.

${ }^{254}$ See Giles S. Rich, Foreword to Chisum et al., supra note 6, at iii, v-vi (noting that it is anachronistic to view the claims as being drafted by inventors rather than by patent attorneys and agents).

255 As discussed supra note 164 and accompanying text, a "PHOSITA" is a "person having ordinary skill in the art."

${ }^{256}$ Fujikawa v. Wattanasin, 93 F.3d 1559, 1570 (Fed. Cir. 1996) (Clevenger, J.). 
number of unmarked trees. Appellants are pointing to trees. We are looking for blaze marks which single out particular trees. ${ }^{257}$

To be sure, the crafting of a disclosure that complies with these rules may itself be difficult; and no disclosure will be perfect. Recent opinions of the various Federal Circuit judges evidence a particular tension about whether this disclosure standard is so fixed, and whether it can be satisfied. ${ }^{258}$ Thus, the disclosure rules

${ }^{257}$ Id. (quoting In re Ruschig, 379 F.2d 990, 994-95 (C.C.P.A. 1967) (Rich, J.)). The well-known biotechnology cases of Amgen, Inc. v. Chugai Pharmaceutical Co., Fiers v. Revel, and Regents of the University of California v. Eli Lilly \& Co. gave some practical teaching about how to satisfy this standard: the applicant must give details about the physical or chemical structure of the claimed invention; merely describing it by function does not suffice. Lilly, 119 F.3d 1559, 1566-69 (Fed. Cir. 1997); Fiers, 984 F.2d 1164, 1168-71 (Fed Cir. 1993); Amgen, 927 F.2d 1200, 1206 (Fed. Cir. 1991). The furniture and computer cases of Gentry Gallery, Inc. v. Berkline Corp. and Lockwood v. American Airlines, Inc. teach that this standard is not technology specific. Gentry, 134 F.3d 1473, 1478-80 (Fed. Cir. 1998) (sofa recliner); Lockwood, 107 F.3d 1565, 1572 (Fed. Cir. 1997) (computer reservation system).

${ }^{258}$ In September 2002, in PIN/NIP, Inc. v. Platte Chemical Co., the Federal Circuit repeated that the test for compliance with the written description requirement requires a comparison of the claims as issued against the disclosure as originally filed, and held invalid a claim not supported by the disclosure of the unamended application. 304 F.3d 1235, 1247-48 (Fed. Cir. 2002). And in October 2002, in All Dental Prodx, LLC v. Advantage Dental Products, Inc., the court reiterated, as in Fujikawa, that the test does not require the disclosure to provide the identical words of the claims, ipsis verbis; the test only requires disclosure to convey the substance of the claim to a PHOSITA. 309 F.3d 774, 779 (Fed. Cir. 2002). But, in January 2003, the court in Amgen Inc. v. Hoechst Marion Roussel, Inc., showed a substantial split in views on the written description requirement. Compare 314 F.3d 1313, 1330-34 (Fed. Cir. Jan. 6, 2003) (majority opinion), with id. at 1358-61 (Clevenger, J., dissenting in part). The majority opinion, written by Judge Paul Michel and joined by Judge Alvin Schall, considered at some length a number of specific written description arguments, but the common theme it reiterated for each was relatively uncontroversial: that the test for compliance is measured against the actual subject matter as claimed, not against its precursors, parts, or gist (as would be the case under a central claiming system). Id. at 1330-34. To the extent the dissent was merely disagreeing on the facts and suggesting that some additional necessary disclosure could have been delivered but was not, the opinion is not doctrinally remarkable. But the language of Judge Raymond Clevenger's dissenting opinion seems to express concern that the majority's approach elevates form over substance and would allow the crafty patentee to avoid the need to disclose as much detail by drafting a broader claim. Id. at 1358-61 (Clevenger, J., dissenting in part). But under the genus/species approach discussed earlier, it flows as a matter of logic that less detail is needed to describe a broader genus. Describing the genus "houses" requires less detail than describing the genus "Victorian houses." That is what the term "broader" means. If the written description were as hard to satisfy as this opinion seems to suggest, then it would raise all of the same objections raised earlier against the information-forcing benefits of a no-DOE system. Finally, other important divisions over the written description requirement are also evident in the court's recent opinions on this topic. See, e.g., MOBA, B.V. v. Diamond Automation, Inc., 325 F.3d 1306 (Fed. Cir. 2003) (including a per curiam opinion from a panel comprising Judges Randall Rader, Schall, and William Bryson, as well as separate concurring opinions by Judges Rader and Bryson), cert. denied, 124 S. Ct. 646 (2003) (mem.); Enzo Biochem, 
themselves to some extent raise many of the same concerns as the DOE. In the final analysis of the tension between the effort to achieve flexibility through either the DOE or the disclosure requirements, the registration theory's contribution is to highlight, as a matter of comparative institutional economics, why reliance on the disclosure rules is less likely to trigger these important concerns as extensively.

\section{Reforms for Deference to the Patent Office}

The patentees' incentive to make their own correct determination of validity also raises serious issues for some of the present administrative law doctrines relating to the Patent Office. ${ }^{259}$ Because the Patent Office regulations governing a patentee's duty to disclose information material to validity provides no added incentive for the patentee to seek out such information, ${ }^{260}$ they may be unnecessary under either a hard-look or a soft-look system. In addition, deference to the Patent Office's decisions on validity as being well-informed is questionable because the Patent Office is not the lower cost provider of information relating to validity. ${ }^{261}$ Moreover, to the extent decisions on validity can be made for so-called legal reasons that are based on facts, there is real potential for social costs relating to public choice and administrative problems in shaping those reasons and how they are applied. ${ }^{262}$

The costs of a hard-look system are, therefore, made worse by the rule of deference. Information about validity over the prior art needed to catch potentially

Inc. v. Gen-Probe, Inc., 285 F.3d 1013 (Fed. Cir. 2002), replaced on reh'g, 323 F.3d 956 (Fed. Cir. 2002) (including a majority opinion authored by Judge Alan Lourie, an opinion concurring in denial of petition for rehearing en banc by Judge Lourie, in which Judge Pauline Newman joined, an opinion concurring in denial of rehearing en banc by Judge Newman, an opinion concurring in denial of rehearing en banc by Judge Timothy Dyk, an opinion dissenting from denial of rehearing en banc by Judge Rader, in which Judges Arthur Gajarsa and Richard Linn joined, and an opinion dissenting from denial of rehearing en banc by Judge Linn, in which Judges Rader and Gajarsa joined). The same objections raised earlier against the information-forcing benefits of a no-DOE system are again triggered to the extent all of these diverse opinions create uncertainty in the eventual application of the written description requirement.

259 These include deference on questions of law and on issues of fact. See supra note 69 (discussing administrative law aspects of the patent system).

${ }^{260}$ See Am. Hoist \& Derrick Co. v. Sowa \& Sons, 725 F.2d 1350, 1362 (Fed. Cir. 1984) (holding that patentee has no duty to search).

${ }^{261}$ See Kerr, supra note 69, at 127-33 (criticizing arguments for deference to the Patent Office); see also In re Lueders, 111 F.3d 1569, 1574-79 (Fed. Cir. 1997) (reviewing reasons for not applying enhanced deference to the Patent Office).

${ }^{262}$ Where the statute has provided the standards against which all claims are to be measured, a shifting in the standards on a case by case basis will return us to the bleak result discussed supra note 227. 
pernicious invalid, or bad, patents is better provided through litigation. In addition, low deference to the agency protects good patents by leaving less room for incorrect decisions on validity grounded in improper application of putative legal rules such as utility, subject matter, and the so-called requirement for invention, each of which has occurred in the past, as discussed earlier. ${ }^{263}$ As a result, many of the proposed shifts towards a hard-look system should be avoided in part because they have a greater potential for public choice and administrative problems, especially under the present regime of heightened deference to the Patent Office. $^{264}$

\section{${ }^{263}$ See supra Part IV.A.}

264 See Dickinson v. Zurko, 527 U.S. 150, 152 (1999) (Administrative Procedures Act requires deference to fact-finding by the Patent Office). Compare Dethmers Mfg. Co. v. Automatic Equip. Mfg. Co., 293 F.3d 1364, 1366-67 (Fed. Cir. 2001) (Dyk, J., dissenting) (questioning court's decision not to give the Patent Office deference on the interpretation of its own regulations), with Merck \& Co. v. Kessler, 80 F.3d 1543, 1549-50 (Fed. Cir. 1996) (holding that the Patent Office should not receive Chevron deference on legal questions because "Congress has not vested the Commissioner with any general substantive rulemaking power").

Especially under a regime of deference, the public choice and administrative problems essentially become those associated with reward theories. Deference to the agency simply provides incentives for individual parties to argue to the agency for policy shifts that target a particular patent or set of patents. This is exactly the move the computer hardware companies made during the late 1960s and early '70s to get the PTO and the Solicitor General's Office to oppose patents on computer software. As described by Judge Rich in dissent in In re Johnston in 1974:

I find it more significant to contemplate the identities of the troops lined up for battle in Benson and observe which side obtained the victory. On the one side was the Government, against patenting programs or software, supported by the collective forces of major hardware (i.e., computer) manufacturers and their representative associations who, for economic reasons, did not want patents granted on programs for their machines. On the other side was Benson et al. and their assignee and assorted lawyers and legal groups who were in favor of patent protection for programs or software. The anti-patenting forces won the victory .... .

502 F.2d 765, 774 (C.C.P.A. 1974) (Rich, J., dissenting) (discussing Gottschalk v. Benson, 409 U.S. 63 (1972)), rev'd on other grounds sub nom. Dann v. Johnston, 425 U.S. 219 (1976). The majority opinion in Benson relies heavily on a 1966 report by a presidential commission on the patent system, which has been described by former Patent Office Commissioner Gerald Mossinghoff:

[T]he 1966 report of the President's Commission on the Patent System was largely a battle between AT\&T, which strongly supported the patenting of software, and IBM, which bitterly opposed it. IBM's position as a mainframe manufacturer and seller was that software should be unpatentable and should be given away free of charge. AT\&T, as primarily a software developer, felt precisely the opposite.

Gregory J. Maier \& Robert C. Mattson, State Street Bank in the Context of the Software Patent Saga, 8 Geo. Mason L. Rev. 307, 316 n.63 (1999) (citing interview with the Honorable Gerald J. Mossinghoff, former Commissioner of Patents and Trademarks, in Arlington, Va. (Sept. 13, 1999)). As such special exceptions stack up over time, the PTO may indeed resemble the "circumlocution office" Dickens described supra note 227. 


\section{Reforms for Post-Issuance Procedures}

Although the registration theory elucidates advantages of soft-look registration systems over hard-look examination systems, a number of middleground approaches might also be considered. These may offer the informational advantages of registration while trying to mitigate the high costs of full civil litigation through various post-issuance procedures to challenge an issued patent but conducted before the Patent Office. Approaches that have been tried include those called ex parte reexamination, inter partes reexamination, and inter partes opposition. $^{265}$

Although ex parte reexamination was introduced into the patent system in 1980 to help address the concerns about the pernicious impact of issued patent claims whose validity is questionable, ${ }^{266}$ it turns out not to work as a costeffective means for removing such claims. This is because it only involves the same parties responsible for allowing the claim in the first instance: the applicant and the Patent Office. ${ }^{267}$ In 1999, inter partes reexamination was introduced to allow for more meaningful participation by third parties. ${ }^{268}$ To prevent patentees

${ }^{265}$ For a discussion of these various procedures, see Chisum et al., supra note 6 , at 128 60.

${ }^{266}$ H.R. Rep. No. 96-1307, pt. 1, at 3-4 (1980), reprinted in 1980 U.S.C.C.A.N. 6460, 6462-63 ("Reexamination will permit efficient resolution of questions about the validity of issued patents without recourse to expensive and lengthy infringement litigation.").

${ }^{267}$ The ex parte nature of the process essentially means that a third party's involvement is limited to the initial request for reexamination. Absent meaningful involvement, this party is not able to present effectively to the decisionmaker the very information relating to validity that the registration theory shows is most likely to be in the hands of some third party. Whatever patent claims emerge from the reexamination will again be presumed valid. Therefore, most third parties have rationally elected to hold any pertinent information relating to validity for later use at trial to undermine the presumption of validity that issued with the patent. Indeed, ex parte reexamination has become a strategic tool for patentees to strengthen effectively their presumption of validity against arguments they suspect may be raised by competitors in litigation. If necessary, the patentee may narrow the claim during reexamination to avoid the newly discovered art, whereas during litigation the court must generally either hold the claim valid or invalid as written. See U.S. Patent and Trademark Office, Performance and Accountability Report Fiscal Year 2001, 106 tbl.1, 119 tbls.13A-B (2001), available at http://www.uspto.gov/web/offices/com/annual/2001 (for the year 2001, 150 of the 296 ex parte reexaminations were requested by third parties and only one was an inter partes reexamination). But see Athletic Alternatives, Inc. v. Prince Mfg., Inc., 73 F.3d 1573, 1581 (Fed. Cir. 1996) (adopting a rule of claim interpretation that is not all or nothing and instead merely narrows the claim scope).

${ }^{268}$ American Inventors Protection Act of 1999, Pub. L. No. 106-113, §§ 4601-4608, 113 Stat. 1501A-552, 1501A-567 to -572 (1999) (adding new sections, 35 U.S.C. $\S \S 311-318$, providing for optional inter partes reexamination procedure). For an excellent review of the strategic concerns raised by this new procedure, see generally Robert T. Pous \& Charles L. Gholz, 
from having their patents held up in perpetual reexamination, however, this new procedure estops the third party, including the real party in interest, from relitigating anything that was or could have been decided during the reexamination. ${ }^{269}$ As a result, third parties who are not yet sure they have the best argument may rationally elect to save it for use in later litigation rather than use it and lose it through the more sterile process of administrative adjudication, which does not allow for consideration of non-documentary forms of evidence. ${ }^{270}$ Inter partes opposition proceedings are used in Europe and allow more types of evidence than the administrative procedures available for reexamination in the United States, but these must be filed within a short time after the patent has issued. $^{271}$

Will Inter Partes Reexamination Be Embraced by Third Parties as an Alternative to Litigation?, 7 Intell. Prop. Today 37 (2000).

${ }^{269}$ See 35 U.S.C. $\S 315$ (c) (2000) ("[Third party] is estopped from asserting at a later time, in any civil action arising in whole or in part under section 1338 of title 28, United States Code, the invalidity of any claim finally determined to be valid and patentable on any ground which the thirdparty requester raised or could have raised during the inter partes reexamination proceedings. [Estoppel] does not prevent the assertion of invalidity based on newly discovered prior art unavailable to the third-party requester and the Patent and Trademark Office at the time of the inter partes reexamination proceedings."); American Inventors Protection Act of 1999 § 4607 (the "1999 Act") ("Any party who requests an inter partes reexamination under section 311 of title 35, United States Code, is estopped from challenging at a later time, in any civil action, any fact determined during the process of such reexamination, except with respect to a fact determination later proved to be erroneous based on information unavailable at the time of the inter partes reexamination decision.").

Importantly, although third parties originally were not allowed under the provisions of the 1999 Act to appeal from the Patent Office to the Federal Circuit, this right of appeal was added in 2002. Patent and Trademark Authorization Act of 2002, Pub. L. No. 107-273, §13106, 2003 U.S.C.C.A.N. (116 Stat.) 1899, 1900-01 (rewriting § 315(b) to expressly provide for this right of appeal to the Federal Circuit through the provisions of $\S \S 141-144$ and rewriting $\S 134$ to delete the express prohibition for this right of appeal); see 35 U.S.C. §315(b)(1) ("A third-party requester ... may appeal under the provisions of section 134, and may appeal under the provisions of sections 141 through 144, with respect to any final decision favorable to the patentability of any original or proposed amended or new claim of the patent ...."); id. §134(c) ("A third-party requester in an inter partes proceeding may appeal to the Board of Patent Appeals and Interferences from the final decision of the primary examiner favorable to the patentability of any original or proposed amended or new claim of a patent, having once paid the fee for such appeal.”).

${ }^{270}$ Unlike litigation, reexamination does not allow for subpoenas, interrogatories, depositions, live testimony, and cross-examination.

${ }^{271}$ See European Patent Convention, Oct. 5, 1973, art. 99(1), available at http://www. european-patent-office.org/legal/epc/index.html (last visited Nov. 13, 2003) (opposition must be filed "[w]ithin nine months from the publication of mention of the grant of the European patent"); see also European Patent Office, Guidelines for Examination in the European Patent Office pt. D, 
An alternative approach might be to include a special provision for declaratory judgment jurisdiction to allow anyone who has sufficient interest, but not necessarily reasonable apprehension of suit, to bring an action in court challenging the validity of the patent. ${ }^{272}$ This would give access to better procedures and would not have the time restrictions of the opposition proceedings, but would then subject patentees to more potential challenges. ${ }^{273}$ In the final analysis, this approach begins to look most like the registration model, which in turn raises a number of litigation conduct issues that are discussed below.

\section{E. Reforms for Litigation}

To be sure, the balancing effect on claim scope that draws the attention of most patent critics is imperfect and must be further explored. These critics are correct that many issued patents are held invalid through federal court litigation. ${ }^{274}$ But the number of patents held invalid has decreased over time. ${ }^{275}$ Critics are also correct that, although many issued patents may be invalid but also

ch. I, at 1, available at http://www.european-patent-office.org/legal/gui_lines/index.htm (setting forth procedural guidelines for opposition proceedings).

272 See Thomas G. Pasternak \& Karen J. Nelson, Side Bar: Declaratory Judgment Jurisdiction: A Dance on the Razor's Edge, in Principles of Patent Law, supra note 6, at 1043, 1043-49 (reviewing the standard for obtaining declaratory judgment jurisdiction in patent cases under present system). Creating such a statutory cause of action to invalidate federally issued patents would help alleviate the problems posed by the constitutional "case and controversy" requirement from Article III, which gave rise to the "reasonable apprehension of suit" prong of the generally applicable test for declaratory judgment jurisdiction. See id. An alternative way to conceptualize this cause of action is the action to quiet title in the real property setting. (Thanks to Henry Smith for this suggestion).

${ }^{273}$ As elucidated by Lemley, one advantage in allowing more time to pass is that it allows more information about society's interest in the patent to accrue, thereby decreasing the likelihood of error associated with ex ante efforts to predict which patents should receive close attention. See supra note 79 and accompanying text (citing Lemley, supra note 6, at 1497).

274 See John R. Allison \& Mark A. Lemley, Empirical Evidence on the Validity of Litigated Patents, 26 Am. Intell. Prop. Law. Ass'n Q.J. 185, 205-07 (1998) (reporting that about $46 \%$ of all patents litigated to a final judgment on validity issues are held invalid, including decisions on appeal and at summary judgment); Moore, supra note 122, at 390 tbl.4 (reporting that $33 \%$ of patents are held invalid at trial).

${ }^{275}$ See Gloria K. Koenig, Patent Invalidity: A Statistical and Substantive Analysis 4-16 to -23 (rev. ed. 1980) (reporting invalidity numbers for the twenty-five year period from 1953 through 1977 as averaging 65.7\% for the courts of appeals and 57.8\% for the district courts); see also Allison \& Lemley, supra note 274, at 206 n.53. 
irrelevant to the market, ${ }^{276}$ some may be invalid and relevant in a bad waythrough their in terrorem effect-without ever reaching litigation. ${ }^{277}$ This leaves alleged infringers to decide among several options: federal court litigation to get the patent adjudicated invalid, obtaining permission from the patentee, or not operating in a way that allegedly infringes. The question raised by such patents is how best to decrease the social costs of allowing the alleged infringer to make and implement the socially optimal decision.

According to the registration theory, these social costs may be decreased by use of tools in the proposed registration model that are slightly modified versions of two recent legal trends in the case law of the present system. ${ }^{278}$ These tools operate to decrease incentives for strategic behavior and increase incentives for sharing information, thereby helping ensure that the alleged infringer is able to make and implement the socially optimal decision on the choice discussed above. $^{279}$

276 This is the important insight explored by Lemley. See supra note 75 and accompanying text.

${ }^{277}$ Not all potential defendants would have elected to spend the money it took to withstand the preliminary injunction in the one-click shopping case discussed supra notes $1-4$ and accompanying text.

${ }^{278}$ These tools come from the general debate over the so-called "American Rule" and the so-called "British Rule" of litigation. As Abramowicz aptly explains:

\begin{abstract}
Loser pays is often called the British rule, though variants of the British rule exist. On the economic choice among the various alternatives, see Richard D. Cooter \& Daniel L. Rubinfeld, Economic Analysis of Legal Disputes and Their Resolution, 27 J. Econ. Lit. 1067 (1989); John J. Donohue III, Opting for the British Rule, or If Posner and Shavell Can't Remember the Coase Theorem, Who Will?, 104 Harv. L. Rev. 1093 (1991); John P. Gould, The Economics of Legal Conflicts, 2 J. Legal Stud. 279 (1973); William M. Landes, An Economic Analysis of the Courts, 14 J.L. \& Econ. 61 (1971); A. Mitchell Polinsky \& Daniel L. Rubinfeld, Does the English Rule Discourage Low-Probability-ofPrevailing Plaintiffs?, 27 J. Legal Stud. 519 (1998); Richard A. Posner, An Economic Approach to Legal Procedure and Judicial Administration, 2 J. Legal Stud. 399 (1973); I.P.L. P'ng, Strategic Behavior in Suit, Settlement, and Trial, 14 Bell J. Econ. 539 (1983); Steven Shavell, Suit, Settlement, and Trial: A Theoretical Analysis Under Alternative Methods for the Allocation of Legal Costs, $11 \mathrm{~J}$. Legal Stud. 55 (1982); Edward A. Snyder \& James W. Hughes, The English Rule for Allocating Legal Costs: Evidence Confronts Theory, 6 J.L. Econ. \& Org. 345 (1990); Mark S. Stein, The English Rule with Client-to-Lawyer Risk Shifting: A Speculative Appraisal, 71 Chi.-Kent L. Rev. 603 (1995); and Bradley L. Smith, Note, Three Attorney Fee-Shifting Rules and Contingency Fees: Their Impact on Settlement Incentives, 90 Mich. L. Rev. 2154 (1992).
\end{abstract}

Michael Abramowicz, Perfecting Patent Prizes 98 n.548 (2001) (working paper, available online at http:/www.law.gmu.edu/faculty/papers/docs/01-29.pdf; this footnote did not appear in the published version of the paper, see Abramowicz, supra note 29).

${ }^{279}$ Neither of these tools was present during the brief window in our history when a true registration system was in use. The registration system lasted for forty-three years, from 1793 to 1836. Indeed, it was not until the Patent Act of 1870 that emphasis was placed on the claim. See Chisum et al., supra note 6, at 19-21. 
The first tool arises from an important innovation in Federal Circuit case law that can be used to decrease incentives for strategic behavior by patentees. Despite the critics' view of the Federal Circuit as a court that is unduly propatentee, the Federal Circuit has led the charge in Rule 11 sanctions in cases such as Judin v. United States, where a discretionary ruling of no sanctions was vacated in 1997 with instructions to award appropriate sanctions against a patentee, and its trial and appellate counsel. ${ }^{280}$ Such disciplining of errant patentees also may be achieved with other similar legal devices including 28 U.S.C. $§ 1927$ (counsel's liability for vexatious litigation), and 35 U.S.C. $§ 285$ (attorney fees for exceptional cases). ${ }^{281}$ Importantly, Judin involved the patentee's failure to conduct a pre-filing investigation on infringement. Under a system like the proposed registration model, such a disciplining device might also be extended to curb patentees' failure to conduct pre-filing investigations on validity.

The second tool arises from a highly evolved body of law in the patent area that can operate to punish clients and their lawyers for reliance on unsatisfactory opinions of counsel. ${ }^{282}$ The standards for opinions of counsel used by alleged infringers to insulate themselves from liability could be applied to potential plaintiff patentees before they are allowed to bring an action claiming liability. This would improve a system like the proposed registration model by spreading the costs of validity determinations among patentees and alleged infringers. The cost-shifting effects discussed above will provide incentives for patentees and likely infringers to exchange information about the strength of their respective cases, thereby somewhat mitigating the risk of duplicative expenditures. This effect is enhanced by the patentee's interest in communicating with alleged infringers so as to make the alleged infringement appear willful and thereby win treble damages. ${ }^{283}$ The essential insight of the registration theory here is that requiring the patentee also to have a good faith belief about patent validity makes this interest in communicating symmetrical - potential infringers will have a similar incentive to communicate validity information to patentees.

Although implementation of these tools would not be a trivial matter, it is conceptually not that difficult. The market for opinions of counsel for both

${ }^{280}$ See 110 F.3d 780, 783-85 (Fed. Cir. 1997) (reversing, for abuse of discretion, a judgment of no sanctions under Rule 11 against patentee and its counsel).

28128 U.S.C. $§ 1927$ (2000); 35 U.S.C. § 285 (2000).

${ }^{282}$ See, e.g., Johns Hopkins Univ. v. CellPro, Inc., 978 F. Supp. 184, 194-96 (D. Del. 1997) (chastising authoring counsel by name while affirming award of treble damages for willful infringement because opinion of counsel was so plainly deficient), aff'd, 152 F.3d 1342 (Fed. Cir. 1998).

283 See Pasternak and Nelson, supra note 272, at 1043-49 (showing how such communications can be conducted without creating declaratory judgment jurisdiction). 
patentees and competitors that is present under the existing system would grow. Cost-sharing techniques would likely evolve, in which groups of interested parties could focus upon a given patent's potential validity or infringement, ${ }^{284}$ rating organizations might arise, ${ }^{285}$ private bounties for pertinent prior art might be offered to increase the information content of opinions, ${ }^{286}$ and shares in potential costs and profits of litigation could be sold. ${ }^{287}$

Although ultimately the subject of an empirical question for further research, the costs associated with these reform proposals are likely to be less than the costs under the existing system - costs associated with those pernicious issued patents presumed to be valid but likely to be held invalid if tested in court. ${ }^{288}$ The combined effect would be positive in several respects. For those patents that are pernicious under the present regime because of the litigation and in terrorem costs they impose on third parties, the proposed reforms would allow third parties to bear only the lower costs associated with the opinion markets, including costs and

${ }^{284}$ These might include formal trade associations or informal groupings of particular people or firms.

${ }^{285}$ The securities markets provide a wealth of examples of fee-based rating organizations, such as Standard \& Poor's ${ }^{\circledR}$.

${ }^{286}$ At least one effort to offer bounties for prior art as a way to help invalidate certain patents has been tried by a company known as BountyQuest. See, e.g., Cade Metz, Has Jeff Bezos Patented Email Discussion Groups? (Mar. 5, 2003), at http://www.pcmag.com/article2 /0,4149,916103,00.asp (discussing ironic role of Amazon.com's Jeff Bezos in founding of the BountyQuest company).

${ }^{287}$ Each of these techniques is used to varying degrees under the existing patent system and under the existing securities registration system upon which the registration model is based. See supra Part II (discussing registration model and its connection to the securities system). I am particularly indebted to Michael Abramowicz, Bernard Black, Joe Grundfest, Arie Michelsohn, and Troy Paredes for conversations on these techniques.

288 Although the reforms are likely to lead to some duplication in the costs associated with searching the art and writing opinions, they will avoid much of the costs under the present system that are associated with litigation or its in terrorem effect. See supra note 277 and accompanying text (discussing these costs). In addition, a broadening of the market for opinions of counsel for both patentees and competitors will help resolve several of the difficult questions associated with opinions of counsel for potential infringers under the present system. For example, the Federal Circuit recently decided to consider en banc the role of adverse inferences when attorney-client privilege or work product immunity is asserted to prevent disclosure of an opinion of counsel and when no opinion has been offered in a case. See Knorr-Bremse Systeme Fuer Nutzfahrzeuge GmbH v. Dana Corp., 344 F.3d 1336, 1336-37 (Fed. Cir. 2003) (per curiam). The privilege and immunity problems are sharpest when they relate to opinions by litigating counsel, and the presence of a broader market for opinions will make it less likely that the pertinent opinion will happen to be from litigating counsel. The problem of no opinion similarly will be mitigated as the broader market for opinions makes them more widely and cheaply available. 
benefits of the fee-shifting techniques. For those patents that have proper scope, ${ }^{289}$ the proposed reforms would allow patentees to have essentially the same costs as under the present system associated with patent drafting and litigation, except that the costs of opinions will decrease slightly (or quality improve slightly) as the market for them becomes more developed. ${ }^{290}$ Finally, one effect that may be seen as positive or negative, depending on point of view, is that there will be a slight decrease in the value of all patents due to the costs to patentees associated with the new need to litigate their own affirmative validity cases. Interestingly, all of these effects combine to yield a system that may be comparatively advantageous over the present system for small players in particular for several reasons: it will save them from the in terrorem effect of junk patents, it will save them their own patent prosecution costs, and they will have ready access to markets to facilitate with funding or strategic partnerships in their own litigation and commercialization efforts when needed. Therefore, according to the registration theory, we should adjust our present system to be more like the registration model by adopting the proposed reforms of weakened or no presumption of validity, fee shifting, and enhanced reliance on opinions of counsel (for both patentees and competitors) to cabin the very pernicious effects explored by advocates of hardlook approaches. ${ }^{291}$

${ }^{289}$ For more on what is meant by proper scope, see supra note 222 and accompanying text.

${ }^{290}$ In addition, under the full registration model, the private costs as well as the public administrative costs associated with patent prosecution and examination would be eliminated for all patents.

291 The reforms proposed here stand in rather stark contrast to several of the recommendations that the Federal Trade Commission offered in its report from the hearings discussed supra in note 5. See Fed. Trade Comm'n, To Promote Innovation: The Proper Balance of Competition and Patent Law and Policy 1-18 (2003), at http://www.ftc. gov/os/2003/10/innovationrpt.pdf (last visited Nov. 13, 2003). Some of the FTC recommendations, such as publication of patents, make great sense under the registration theory. See id. at 15-16 (Recommendation 7). Some, such as elimination of the substantive presumption of validity, and post-grant review of patents, may be consistent with the registration model if properly implemented. See id. at 7-10 (Recommendations 1-2). But, for the reasons explored throughout this Article, under the registration theory many should be avoided, such as a change in the patent-obtaining rules relating to nonobviousness, utility, and subject matter, as well as the vague concern about economic impact, a change in the patent enforcement rules relating to notice and so-called prior user rights, increased funding for the Patent Office, more involved examination, and increased deference to Patent Office decisions. See id. at 10-17 (Recommendations 3-6, 8-10).

Interestingly, the FTC recommendations very closely track data recently gathered and reported by Iain M. Cockburn of the Boston University School of Management and the National Bureau of Economic Research and Rebecca Henderson of the Massachusetts Institute of Technology's Sloan School and also of the National Bureau of Economic Research. This 


\section{CONCLUSION}

Patent law can operate to minimize social costs, including those typically associated with information, administration, public choice, races for a common prize, and bargaining. The case for an alternative model registration system helps reveal, for the first time, a normative theory of the law and economics of the positive law patent-obtaining rules called the registration theory. The case for an alternative model registration system also is helpful in showing why increased scrutiny of patent applications would worsen, not improve, the present system's performance.

Some may argue that a full-blown shift to registration may not be optimal. Indeed, the present patent system already has evolved some powerful disciplining tools that restrict patents' ability to cause many of the social costs that prompted criticism. To the extent this effect should be increased, it may be beneficial to dial back somewhat the presumption of validity and increase the patentee's burdens of conducting pre-filing investigations on both infringement and validity before bringing suit to enforce a patent.

Finally, regardless of the prescriptive aspects of this Article, the new normative registration theory for the patent-obtaining rules offered herein turns out to have more explanatory power than the reward, prospect, and rent dissipation theories in the literature. The registration theory thereby contributes to the literature by both elucidating how and why these rules operate and by serving as a new lens through which subsequent reforms can be judged

information was gathered from a survey conducted in the late summer of 2002 of senior intellectual property managers at large companies and was sponsored by the Intellectual Property Owners Association. This close correlation between the recommendations in the FTC report and the results of the survey is consistent with the view that some leaders in the field think the agency "got it right." But this data does not speak to whether the agency "got it right" in the view of the same people at a different time or other people situated differently, such as those who work in small and medium-sized businesses, or those who endeavor to approach the issue without any specific client with a present specific agenda in mind. I am grateful to Iain and Rebecca for generously sharing the results of their data with me. Interview with Iain M. Cockburn, Professor of Finance and Economics, Boston University School of Management, in Boston, Mass. (Nov. 11, 2003). 